\title{
Onchocerciasis drug development: from preclinical models to humans
}

\author{
Adela Ngwewondo $^{1,2} \cdot$ Ivan Scandale ${ }^{2} \cdot$ Sabine Specht $^{2}$ (1)
}

Received: 15 June 2021 / Accepted: 30 August 2021 / Published online: 13 October 2021

(c) The Author(s) 2021

\begin{abstract}
Twenty diseases are recognized as neglected tropical diseases (NTDs) by World Health Assembly resolutions, including human filarial diseases. The end of NTDs is embedded within the Sustainable Development Goals for 2030, under target 3.3. Onchocerciasis afflicts approximately 20.9 million people worldwide with $>90 \%$ of those infected residing in Africa. Control programs have made tremendous efforts in the management of onchocerciasis by mass drug administration and aerial larviciding; however, disease elimination is not yet achieved. In the new WHO roadmap, it is recognized that new drugs or drug regimens that kill or permanently sterilize adult filarial worms would significantly improve elimination timelines and accelerate the achievement of the program goal of disease elimination. Drug development is, however, handicapped by high attrition rates, and many promising molecules fail in preclinical development or in subsequent toxicological, safety and efficacy testing; thus, research and development (R\&D) costs are, in aggregate, very high. Drug discovery and development for NTDs is largely driven by unmet medical needs put forward by the global health community; the area is underfunded and since no high return on investment is possible, there is no dedicated drug development pipeline for human filariasis. Repurposing existing drugs is one approach to filling the drug development pipeline for human filariasis. The high cost and slow pace of discovery and development of new drugs has led to the repurposing of "old" drugs, as this is more cost-effective and allows development timelines to be shortened. However, even if a drug is marketed for a human or veterinary indication, the safety margin and dosing regimen will need to be re-evaluated to determine the risk in humans. Drug repurposing is a promising approach to enlarging the pool of active molecules in the drug development pipeline. Another consideration when providing new treatment options is the use of combinations, which is not addressed in this review. We here summarize recent advances in the late preclinical or early clinical stage in the search for a potent macrofilaricide, including drugs against the nematode and against its endosymbiont, Wolbachia pipientis.
\end{abstract}

Keywords Onchocerciasis · Macrofilaricide $\cdot$ Microfilaricide $\cdot$ Preclinical models $\cdot$ Clinical trials $\cdot$ Mode of action $\cdot$ Drug development

\section{Onchocerciasis}

Onchocerciasis remains a leading cause of debilitating skin and ocular disease in endemic regions in Africa and the Arabian Peninsula. It is a vector-borne parasitic disease caused by the filarial nematode Onchocerca volvulus (Burnham

\section{Handling Editor: Julia Walochnik.}

Sabine Specht

sspecht@dndi.org

1 Centre of Medical Research, Institute of Medical Research and Medicinal Plants Studies (IMPM), P.O. Box13033, Yaoundé, Cameroon

2 Drugs for Neglected Diseases Initiative, Chemin Camille-Vidart 15, 1202 Geneva, Switzerland
1998). Arthropod vectors (Simulium spp.) acquire L1 larval stages (microfilariae, $\mathrm{mf}$ ) during a blood meal from the human host; L1 larvae subsequently moult twice to the L3 (infective) stage in the vector and are then introduced into a new host during a blood meal where they subsequently develop to adult stages. L3 larvae moult inside the human host to L4 and then L5 stages before maturing to adults over a period of months. In the human body, adult worms produce larvae (microfilariae) that migrate to the skin, eyes and other organs. When a female blackfly bites an infected person during a blood meal, it ingests the skin-dwelling microfilariae which develop and are subsequently transmitted to the next human host.

A subcutaneous nodule is formed around the female worms, the core of which is a dense infiltrate of inflammatory cells. 
Male adults migrate between nodules, where they fertilize sedentary females. After mating, females release thousands of microfilariae into the surrounding tissues, where they can be ingested by feeding black flies to complete the life cycle.

Most clinical manifestations associated with $O$. volvulus are related to the chronic effects of repeated episodes of inflammation induced by the death of microfilariae and most likely also their Wolbachia endosymbionts. Skin disease is caused by inflammation around skin-dwelling microfilariae; it presents primarily as a generalized papular dermatitis and rarely as hyperreactive localized onchodermatitis ("sowda"). Infection with $O$. volvulus can cause visual impairment and blindness, including anterior segment disease with sclerosing keratitis and iridocyclitis, and posterior segment disease with optic atrophy and chorioretinopathy (Nutman 2020).

Microfilariae have been targeted by chemotherapeutic mass treatment with ivermectin (IVM), which is currently the most important drug for the treatment of onchocerciasis. It is well tolerated, highly efficacious and rapidly reduces microfilarial numbers in the skin (Aziz et al. 1982). Ivermectin significantly reduces the itching of reactive onchocercal skin disease (Brieger et al. 1998); however, because microfilariae can re-invade the skin within 6 months of treatment, annual treatments may not be sufficient to control pruritus, and treatment every 3 months may be necessary for the first 1 to 2 years. Sub-optimal efficacy has been observed in patients endemic in areas repeatedly treated with ivermectin (Osei-Atweneboana et al. 2007).

The Global Burden of Disease Study in 2017 estimated that 20.9 million people are infected with $O$. volvulus worldwide; 14.6 million of those infected suffer from skin disease and 1.15 million have experienced vision loss (Global Burden of Disease 2018).

\section{Current treatment strategy}

The initial effort of the West African Onchocerciasis Control Program (OCP) to reduce disease, which focused on eliminating the vector using aerial larvaciding, was greatly enhanced in 1987 by preventive chemotherapy (PC) with ivermectin donated by Merck \& Co. In 1995, the use of ivermectin for onchocerciasis was extended to cover all endemic countries in Africa with the establishment of the African Programme for Onchocerciasis Control (APOC). APOC was formed with the extended mandate of reducing the prevalence of both blinding and dermatological disease by distributing ivermectin on an annual basis to all (above 5 years of age, not pregnant) living in meso-and hyper-endemic communities. With the closure of APOC in 2015, onchocerciasis elimination efforts across Africa are now under the auspices of the Expanded Special Project for Elimination of Neglected Tropical Diseases (ESPEN) with the aim for disease control as a "public health problem" shifting now to "elimination of transmission", as formulated in the new World Health Organisation (WHO) NTD Roadmap (WHO 2020).

Four out of six countries in the Americas have been verified by WHO as free of onchocerciasis after successful implementation of elimination activities: Colombia, Ecuador, Mexico and Guatemala (Sauerbrey et al. 2018). The regional focus is now on the remaining active transmission zone, called the Yanomami Area, on the border between Venezuela and Brazil. Both countries have difficult political climates that hinder the elimination task in this remote and neglected region.

Elimination of transmission has been also achieved in focal areas of Africa (e.g. Sudan, Uganda and Ethiopia (Global Burden of Disease 2018). The global effort against onchocerciasis has been one of the most successful public health initiatives in tropical medicine of the past century. To ensure continuous success and hinder recrudescence in any of these sites, surveillance studies are indispensable.

\section{Limitations of current MDA strategies}

The success and effectiveness of Mass Drug Administration (MDA) are highly dependent on treatment coverage and precontrol endemicity (Turner et al. 2014; Coffeng et al. 2014; Stolk et al. 2015). An effective, affordable and feasible way forward is under continual discussion, and several limitations of the MDA programme have been identified.

Onchocerciasis foci have been classified epidemiologically, according to infection prevalence, into hyper-endemic (>60\%), mesoendemic (30-60\%) and hypo-endemic $(<30 \%)$. Previously, hyper- and mesoendemic areas were targeted, but not hypo-endemic areas. With the major shift taking place in the last few years to move from the control of the disease as a "public health problem" to "elimination of transmission", hypo-endemic areas are now also included, as they remain a source of ongoing infection. One of the greatest challenges facing this new goal is the need to remap endemic areas of onchocerciasis to allow optimal IVM distribution.

Another consideration is that coinfection with Loa loa hinders elimination efforts in countries such as Nigeria, Cameroon, Ethiopia, Uganda and Congo (WHO 2014) because treatment with IVM of persons with high-level Loa loa microfilaremia can trigger serious complications, including meningoencephalitis (Boussinesq et al. 2003). These areas were previously excluded from MDA, making the coverage of current MDA programs incomplete. A new strategy termed "Test and Not Treat" (TaNT), based on the use of the LoaScope to estimate L. loa microfilaraemia before treatment to exclude heavily infected patients, could 
allow safe implementation of MDA in loiasis endemic areas (Lenk et al. 2020; Boussinesq et al. 2018). However, this has not yet been implemented on a large scale.

Non-compliance has been another major issue during MDA campaigns. Although not analysed systematically, post-treatment adverse events have been a major reason for refusing IVM intake. This was systematically addressed in a recent study in a Loa loa-coendemic area (Forrer et al. 2021). Furthermore, the reasons for non-compliance were analysed in two health districts in the western region of Cameroon. Disease prevalence remained high in these areas, despite the annual distribution of IVM since 1996. Nearly $30 \%$ of the population did not take IVM during the most recent round of MDA and there was a significant proportion of the population that had reportedly never taken the drug (Katabarwa et al. 2013). The key factors associated with drug adherence were related to either programmatic and delivery issues, primarily absenteeism at the time of the campaign, or individual determinants, such as side effects associated with the drug, ethnicity, age and years lived in the village. Efforts should also include social scientists in control programs to better understand and reduce the systematic non-compliance in certain groups are likely to be important in ensuring the interruption of transmission in the study area (Senyonjo et al. 2016).

After years of implementation, MDA programme fatigue should also be considered, as individuals in an endemic area may find repeated MDA inconvenient or may lose confidence in the MDA campaign. The benefits of effective MDA for the entire population clearly exceed the risk, but when prevalence is reduced, the risk/benefit ratio may narrow considerably. Unlike a vaccine, MDA for onchocerciasis does not provide an immediate benefit for an uninfected person, potentially leading to an additional lack of treatment adherence.

Other equally important factors include areas being difficult to treat due to ongoing conflict, lack of financial resources and inadequate political engagement, for example in the Democratic Republic of Congo (Makenga et al. 2015).

Finally, obtaining up-to-date data on remaining transmission zones and monitoring elimination efforts are critical to the success of the global programme for onchocerciasis control, as the accurate mapping will allow targeted interventions and provide the information needed to guide decisions on when to stop MDA. To do this, improved diagnostic tests are urgently needed to fine-tune elimination efforts.

In April 2020, the WHO published a new roadmap for NTDs for the period 2021-2030, which aims to guide countries towards achieving Sustainable Development Goal 3.3, to ensure healthy lives and promote well-being for all at all ages and to end endemic NTDs by 2030. It proposes important shifts for NTD programs, which will be fundamental to sustaining the progress in control of NTDs, including filarial diseases. The need for strong country ownership, including domestic funding, and a more holistic approach to address cross-cutting development issues has been recognized, and programs and activities to fight NTDs should be further combined across diseases to achieve a maximum return on investment. It has also been recognized that additional tools, including the development of a macrofilaricide as an alternative strategy (WHO 2020; Walker et al. 2017a), are needed to significantly reduce the timelines for elimination as part of the strategy (NTD Modelling Consortium Onchocerciasis Group. Gates Open Res. 2019).

\section{Drug discovery in onchocerciasis}

Before any new drug is tested in clinical trials, its safety and efficacy must be evaluated through streamlined processes and well-established tests. Assessment of the preclinical safety profile follows clear harmonized guidelines, while a demonstration of efficacy is far more complicated. In vitro and in vivo models serve to demonstrate efficacy against the whole parasite and/or specific molecular targets (protein, RNA molecule, etc.) Drug discovery in veterinary parasitology, therefore, consists of two complementary lead identification strategies and includes phenotypic screening (whole organism) and target-based screening (enzymes, receptors). Whereas target-based screens benefit from technological advances in structural biology, computational chemistry, structure-based drug design, genomics and proteomics, coupled with enhanced automation in high-throughput screening platforms and combinatorial chemistry strategies, most antiparasitic products were discovered by the phenotypic screening of synthetic and natural compounds against intact/whole parasites, either in culture or in animal models (Selzer and Epe 2020). Because of limited resources available for human NTDs, drug discovery relies predominantly on phenotypic screening and only a few biological targets have been described and validated.

In veterinary drug discovery, molecules can be evaluated in infection models matching the pathologies of the animals which are the final beneficiaries. As human pathogens are often not viable in animal hosts, drug discovery for humans relies on surrogate parasites for in vitro and in vivo assays. Therefore, the trickiest question in drug development for filarial parasites has always been: which is the most predictive model for selecting a drug candidate and predicting efficacy in humans? The simple answer is that there isn't one. Every host-parasite combination has its own strengths and limitations. Foremost, the larval biology of filarial worms presents common, but also clearly distinct, features, such as the location of the parasite, the parasite-host interaction and clinical presentation within the host. To select novel and effective anti-filarial drugs, all available information 
(activity in vitro against different worm stages, activity in different in vivo models, pharmacokinetic parameters in the final hosts, etc.) should be carefully reviewed, as none of the existing models fully reflects the situation in human filarial infections. These aspects must be considered when interpreting an animal model for testing or predicting drug efficacy.

The standards of care for several filarial infections, IVM and diethylcarbamazine (DEC) for lymphatic filariasis, are potent inhibitors of microfilaremia which have been remarkably successful in reducing transmission and clinical symptoms in humans. It is, however, important to note that although these molecules are ineffective in vitro at relevant clinical concentrations, they are efficacious in animal models of filariasis. Such a disconnect with reference drugs hinders the setup of a straightforward "one-fits-all" screening cascade. Many publications report the parallel testing of a drug in different rodent models to check for consistency of activity across models. However, in the absence of a clinically validated macrofilaricidal treatment, the translation of all these models remains unknown. Therefore, a sensible approach to deciding whether to move a compound forward should be based on the identification of the pharmacokinetic/pharmacodynamic relationship and the mechanism of action. This information is indeed crucial to guiding clinical development and to predicting regimens with reasonable efficacy in humans.

Onchocerca volvulus has recently been successfully established for in vitro testing (Voronin et al. 2019; Gandjui et al. 2021) but maintaining it under experimental conditions requires a great effort, and no permissive animal model exists. The infection of fully immunocompetent $\mathrm{BALB} / \mathrm{c}$ mice with infective third-stage $L$. sigmodontis larvae (L3) results in patent infections with circulating microfilariae. Alternative surrogate models are Brugia pahangi (host: rodent, human), Acanthochieloma viteae (host: jirds), Onchocerca gutturosa (host: cattle), Onchocerca linealis (host: cattle) and O. Ochengi (host: cattle) (Morris et al. 2013). Recent attempts tried to overcome this problem by using transgenic rodent hosts, modified to tolerate human filarial species (Patton et al. 2018; Pionnier et al. 2020).

Intracellular bacteria in filarial nematodes were discovered in the 1970s with the advent of electron microscopy. It was speculated that these bacteria were related to insect $\mathrm{Wol}$ bachia symbionts and suggested that these bacteria might contribute to the pathogenesis of the filarial disease, making them a novel target for anti-filarial chemotherapy (reviewed in Taylor and Hoerauf 1999). In the beginning of the 2000s, Wolbachia resurfaced as a promising target for the treatment of human filariasis (reviewed in Taylor et al. 2005). Depletion of Wolbachia results in the inhibition of embryogenesis and thus a slow decline of circulating microfilariae, followed by adult worm death (Hoerauf et al. 2008); this has been shown using tetracyclines in humans (Table 1) as well as in animal models (Bosshardt et al. 1993; Volkmann et al. 2003;
Walker et al. 2015; Aljayyoussi et al. 2017) (Table 2). In contrast to the difficulties described for direct-acting drugs, the identification of this indirect mode of action by Wolbachia depletion has enabled the setting up of an efficient screening cascade to allow for high-throughput screening of anti-bacterial drugs (Johnston et al. 2014).

\section{Direct-acting drugs}

\section{Ivermectin (IVM)}

Historical chemotherapeutic treatments for onchocerciasis, such as suramin and DEC, were of limited efficacy and/or safety (Awadzi and Gilles 1992, Budden 1976; Duke 1968). Neither intervention was suitable for MDA, and both drugs have been removed from use for onchocerciasis. The situation changed with the introduction of IVM. Streptomyces avermitilis, a microbe that produces anthelmintic avermectins, was isolated from a soil sample obtained on a Japanese golf course in a project led by Satoshi Omura at the Kitasato Institute, and the commercial product IVM was then obtained and developed by a team led by William Campbell at Merck \& Co. Both researchers were rightfully acknowledged with the Nobel Prize in Medicine in 2015 for the impact of their discovery on global health. IVM has been shown to be also active against human ectoparasites like lice and rabies (Youssef et al. 1995). Based on its activity against filarial parasites of veterinary significance, in particular Dirofilaria immitis (Campbell 1983), but also in other experimental animal models, IVM was tested in human patients with onchocerciasis and shown to be effective as a prolonged action microfilaricide after a single oral dose, with few side effects (see Table 1). Adult worms examined after nodulectomy were found to have prolonged suppression of microfilarial production. In the mid-1980s, IVM became the first-choice drug for onchocerciasis, due to its safety profile in microfilaremic patients. Several studies led to its registration, comparing its efficacy against DEC and identifying the reasonable dose to be used in MDA (Greene et al. 1985; Lariviere et al. 1985; Diallo et al. 1986; Awadzi et al. 1986; White et al. 1987). The results suggested that there is no advantage in administering doses $>150 \mu \mathrm{g} / \mathrm{kg}$ and that the higher dose of $200 \mu \mathrm{g} / \mathrm{kg}$ may be associated with an increased incidence of adverse effects. Additional data and a longer follow-up period would be needed to clearly assess the performance of this dose compared with $100 \mu \mathrm{g} /$ $\mathrm{kg}$. Thus, $150 \mu \mathrm{g} / \mathrm{kg}$ was chosen as the dose of IVM for use in onchocerciasis control programmes. A higher dose $(800 \mu \mathrm{g} / \mathrm{kg})$ was tested for macrofilaricidal efficacy; IVM at $150 \mu \mathrm{g} / \mathrm{kg}$ or $800 \mu \mathrm{g} / \mathrm{kg}$ given every 3 months had some macrofilaricidal effects, but of insufficient magnitude to warrant incorporation into MDA programs (Gardon et al. 2002). 
Table 1 Major clinical trials in onchocerciasis drug development

\begin{tabular}{|c|c|c|c|c|}
\hline & Drug name & Study title & Clinical trial identifier & Reference \\
\hline \multicolumn{5}{|c|}{ Direct-acting drugs } \\
\hline \multirow[t]{19}{*}{1} & Ivermectin & $\begin{array}{l}\text { Efficacy and tolerance of ivermectin in human } \\
\text { onchocerciasis }\end{array}$ & None & Aziz et al. (1982) \\
\hline & & $\begin{array}{l}\text { Management in Senegal of the 1st efficacy and } \\
\text { tolerability studies of ivermectin (MK 933) in } \\
\text { human onchocerciasis }\end{array}$ & & Diallo et al. (1984) \\
\hline & & $\begin{array}{l}\text { The chemotherapy of onchocerciasis X. An } \\
\text { assessment of four single dose treatment } \\
\text { regimes of MK-933 (ivermectin) in human } \\
\text { onchocerciasis }\end{array}$ & None & Awadzi et al. (1985) \\
\hline & & $\begin{array}{l}\text { Comparison of ivermectin and diethylcarbama- } \\
\text { zine in the treatment of onchocerciasis }\end{array}$ & None & Greene et al. (1985)* \\
\hline & & $\begin{array}{l}\text { Double-blind study of ivermectin and diethyl- } \\
\text { carbamazine in African onchocerciasis } \\
\text { patients with ocular involvement }\end{array}$ & None & Lariviere et al. (1985)* \\
\hline & & $\begin{array}{l}\text { A double-blind comparison of the efficacy and } \\
\text { safety of ivermectin and diethylcarbamazine } \\
\text { in a placebo-controlled study of Senegalese } \\
\text { patients with onchocerciasis }\end{array}$ & None & Diallo et al. (1986)* \\
\hline & & $\begin{array}{l}\text { The chemotherapy of onchocerciasis. XI. A } \\
\text { double-blind comparative study of ivermectin, } \\
\text { diethylcarbamazine and placebo in human } \\
\text { onchocerciasis in northern Ghana }\end{array}$ & None & Awadzi et al. (1986)* \\
\hline & & $\begin{array}{l}\text { Treatment of onchocerciasis. The ocular effects } \\
\text { of ivermectin and diethylcarbamazine }\end{array}$ & None & Taylor et al. (1986) \\
\hline & & $\begin{array}{l}\text { Controlled trial and dose-finding study of iver- } \\
\text { mectin for treatment of onchocerciasis }\end{array}$ & None & White et al. (1987)* \\
\hline & & $\begin{array}{l}\text { Ocular findings in a double-blind study of } \\
\text { ivermectin versus diethylcarbamazine versus } \\
\text { placebo in the treatment of onchocerciasis }\end{array}$ & None & Dadzie et al. (1987) \\
\hline & & $\begin{array}{l}\text { Ivermectin effect on microfilariae of Oncho- } \\
\text { cerca volvulus after a single oral dose in } \\
\text { humans }\end{array}$ & None & Soboslay et al. (1987) \\
\hline & & $\begin{array}{l}\text { Ivermectin in the treatment and prevention of } \\
\text { human onchocerciasis }\end{array}$ & None & Lariviere et al. (1987) \\
\hline & & $\begin{array}{l}\text { Effect of single-dose ivermectin therapy on } \\
\text { human Onchocerca volvulus infection with } \\
\text { onchocercal ocular involvement }\end{array}$ & None & Newland et al. (1988) \\
\hline & & $\begin{array}{l}\text { Ivermectin and human onchocerciasis. A study } \\
\text { of } 234 \text { onchocerciasis patients in the Republic } \\
\text { of Mali }\end{array}$ & None & Vingtain et al. (1988) \\
\hline & & $\begin{array}{l}\text { Emergence of Onchocerca volvulus microfilar- } \\
\text { iae from skin snips before and after treatment } \\
\text { of patients with ivermectin }\end{array}$ & None & Mössinger et al. (1988) \\
\hline & & $\begin{array}{l}\text { A multi-centre study of the effect of Mectizan treat- } \\
\text { ment on onchocercal skin disease: clinical findings }\end{array}$ & None & $\begin{array}{l}\text { Ogbuagu and Eneanya } \\
\text { (1988) }\end{array}$ \\
\hline & & $\begin{array}{l}\text { Studies with ivermectin in onchocerciasis } \\
\text { patients in northern Ghana, a region with long } \\
\text { lasting vector control }\end{array}$ & None & Awadzi et al. (1989) \\
\hline & & $\begin{array}{l}\text { Ivermectin treatment of patients with severe } \\
\text { ocular onchocerciasis }\end{array}$ & None & Taylor et al. (1989) \\
\hline & & $\begin{array}{l}\text { Ophthalmological results from a placebo con- } \\
\text { trolled comparative } 3 \text {-dose ivermectin study in } \\
\text { the treatment of onchocerciasis }\end{array}$ & None & Dadzie et al. (1989) \\
\hline
\end{tabular}


Table 1 (continued)

\begin{tabular}{|c|c|c|c|}
\hline Drug name & Study title & Clinical trial identifier & Reference \\
\hline & $\begin{array}{l}\text { A study in the Ivory Coast (1985-1987) of the } \\
\text { efficacy and tolerance of ivermectin (Mectizan) } \\
\text { in human onchocerciasis. I. A comparative } \\
\text { double-blind study of } 220 \text { patients with oncho- } \\
\text { cerciasis treated with a single oral dose of } 100 \text {, } \\
150 \text { or } 200 \mathrm{mcg} / \mathrm{kg}\end{array}$ & None & Lariviere et al. (1989) \\
\hline & $\begin{array}{l}\text { Effects of diethylcarbamazine and ivermectin on } \\
\text { the mobilization of microfilariae of Oncho- } \\
\text { cerca volvulus }\end{array}$ & None & Basset et al. (1989) \\
\hline & $\begin{array}{l}\text { Lack of adverse reactions in ivermectin treat- } \\
\text { ment of onchocerciasis }\end{array}$ & None & De Sole et al. (1990) \\
\hline & $\begin{array}{l}\text { Effects of multiple monthly doses of ivermectin } \\
\text { on adult Onchocerca volvulus }\end{array}$ & None & Duke et al. (1990) \\
\hline & $\begin{array}{l}\text { Viability of adult Onchocerca volvulus after six } \\
\text { 2-weekly doses of ivermectin }\end{array}$ & None & Duke et al. (1991a) \\
\hline & $\begin{array}{l}\text { Comparison of the effects of a single dose and } \\
\text { of four six-monthly doses of ivermectin on } \\
\text { adult Onchocerca volvulus }\end{array}$ & None & Duke et al. (1991b) \\
\hline & $\begin{array}{l}\text { A community trial of ivermectin for onchocer- } \\
\text { ciasis in Sierra Leone: adverse reactions after } \\
\text { the first five treatment rounds }\end{array}$ & None & Whitworth et al. (1991a) \\
\hline & $\begin{array}{l}\text { Effects of repeated doses of ivermectin on } \\
\text { ocular onchocerciasis: community-based trial } \\
\text { in Sierra Leone }\end{array}$ & None & Whitworth et al. (1991b) \\
\hline & $\begin{array}{l}\text { A comparison of 6-, 12-, and 24-monthly dosing } \\
\text { with ivermectin for treatment of onchocerciasis }\end{array}$ & None & Greene et al. (1991) \\
\hline & $\begin{array}{l}\text { Effects of three-month doses of ivermectin on } \\
\text { adult Onchocerca volvulus }\end{array}$ & None & Duke et al. (1992) \\
\hline & $\begin{array}{l}\text { A community trial of ivermectin for onchocer- } \\
\text { ciasis in Sierra Leone: clinical and parasi- } \\
\text { tological responses to four doses given at } \\
\text { six-monthly intervals }\end{array}$ & None & Whitworth et al. (1992a) \\
\hline & $\begin{array}{l}\text { Ivermectin does not reduce the burden of itching } \\
\text { in an onchocerciasis endemic community }\end{array}$ & None & Whitworth et al. (1992b) \\
\hline & $\begin{array}{l}\text { Tolerance of ivermectin treatment of rural com- } \\
\text { munities infected by savannah onchocerciasis } \\
\text { in Mali }\end{array}$ & None & Soula et al. (1992) \\
\hline & $\begin{array}{l}\text { The effect of repeated doses of ivermectin on adult } \\
\text { female Onchocerca volvulus in Sierra Leone }\end{array}$ & None & Chavasse et al. (1992) \\
\hline & $\begin{array}{l}\text { Reduction in incidence of optic nerve disease with } \\
\text { annual ivermectin to control onchocerciasis }\end{array}$ & None & Abiose et al. (1993) \\
\hline & $\begin{array}{l}\text { Adverse reactions to ivermectin treatment for } \\
\text { onchocerciasis. Results of a placebo-con- } \\
\text { trolled, double-blind trial in Malawi }\end{array}$ & None & Burnham (1993) \\
\hline & $\begin{array}{l}\text { A community-based trial of ivermectin for } \\
\text { onchocerciasis control in the forest of south- } \\
\text { western Cameroon: clinical and parasitologic } \\
\text { findings after three treatments }\end{array}$ & None & Somo et al. (1993) \\
\hline & $\begin{array}{l}\text { Community treatment with ivermectin for } \\
\text { onchocerciasis in the east Usambara mountains }\end{array}$ & None & Mwetta and Hills (1994) \\
\hline & $\begin{array}{l}\text { A trial of a three-dose regimen of ivermectin for } \\
\text { the treatment of patients with onchocerciasis } \\
\text { in the UK }\end{array}$ & None & Churchill et al. (1994) \\
\hline
\end{tabular}

Transient changes in cytokine profiles following None ivermectin treatment of onchocerciasis

Steel et al. (1994) 
Table 1 (continued)

\begin{tabular}{|c|c|c|c|}
\hline Drug name & Study title & Clinical trial identifier & Reference \\
\hline & $\begin{array}{l}\text { Ivermectin and onchocercal optic neuritis: } \\
\text { short-term effects }\end{array}$ & None & Murdoch et al. (1994) \\
\hline & $\begin{array}{l}\text { The chemotherapy of onchocerciasis. XIX: The } \\
\text { clinical and laboratory tolerance of high dose } \\
\text { ivermectin }\end{array}$ & None & Awadzi et al. (1995) \\
\hline & $\begin{array}{l}\text { Ivermectin treatment of onchocercal skin } \\
\text { lesions: observations from a placebo-con- } \\
\text { trolled, double-blind trial in Malawi }\end{array}$ & None & Burnham (1995) \\
\hline & $\begin{array}{l}\text { Effets secondaires du traitement de la loase } \\
\text { hypermicrofilarémique par l'ivermectine [Sec- } \\
\text { ondary effects of the treatment of hypermicro- } \\
\text { filaremic loiasis using ivermectin] }\end{array}$ & None & Ducorps et al. (1995) \\
\hline & $\begin{array}{l}\text { Irreversible effects of ivermectin on adult para- } \\
\text { sites in onchocerciasis patients in the Oncho- } \\
\text { cerciasis Control Programme in West Africa }\end{array}$ & None & Plaisier et al. (1995) \\
\hline & $\begin{array}{l}\text { The effects of multiple doses of ivermectin on } \\
\text { ocular onchocerciasis. A six-year follow-up }\end{array}$ & None & Mabey et al. (1996) \\
\hline & $\begin{array}{l}\text { A community trial of ivermectin for oncho- } \\
\text { cerciasis in Sierra Leone: compliance and } \\
\text { parasitological profiles after three and a half } \\
\text { years of intervention }\end{array}$ & None & Whitworth et al. (1996a) \\
\hline & $\begin{array}{l}\text { Clinical and parasitological responses after } \\
\text { up to } 6.5 \text { years of ivermectin treatment for } \\
\text { onchocerciasis }\end{array}$ & None & Whitworth et al. (1996b) \\
\hline & $\begin{array}{l}\text { An improved dosing schedule for ivermectin as } \\
\text { a microfilaricidal agent against onchocerciasis }\end{array}$ & None & Shu et al. (1997) \\
\hline & $\begin{array}{l}\text { Impact of annual dosing with ivermectin on } \\
\text { progression of onchocercal visual field loss }\end{array}$ & None & Cousens et al. (1997) \\
\hline & $\begin{array}{l}\text { The effects of ivermectin on onchocercal skin } \\
\text { disease and severe itching: results of a multi- } \\
\text { centre trial }\end{array}$ & None & Brieger et al. (1998) \\
\hline & $\begin{array}{l}\text { The effects of high-dose ivermectin regimens on } \\
\text { Onchocerca volvulus in onchocerciasis patients }\end{array}$ & None & Awadzi et al. (1999) \\
\hline & $\begin{array}{l}\text { Effect of repeated ivermectin treatments on } \\
\text { ocular onchocerciasis: evaluation after six to } \\
\text { eight doses }\end{array}$ & None & Chippaux et al. (1999) \\
\hline & $\begin{array}{l}\text { A controlled prospective trial of the prophylac- } \\
\text { tic effect of a single dose of ivermectin against } \\
\text { Onchocerca volvulus }\end{array}$ & None & $\begin{array}{l}\text { Boussinesq and Chippaux } \\
\text { (2001) }\end{array}$ \\
\hline & $\begin{array}{l}\text { Immunocompetence may be important in the } \\
\text { effectiveness of Mectizan (ivermectin) in the } \\
\text { treatment of human onchocerciasis }\end{array}$ & None & Ali et al. (2002) \\
\hline & $\begin{array}{l}\text { Effects of standard and high doses of ivermectin } \\
\text { on adult worms of Onchocerca volvulus: a } \\
\text { randomised controlled trial }\end{array}$ & None & Gardon et al. (2002) \\
\hline & $\begin{array}{l}\text { Thirty-month follow up of sub-optimal respond- } \\
\text { ers to multiple treatments with ivermectin, in } \\
\text { two onchocerciasis endemic foci in Ghana }\end{array}$ & None & Awadzi et al. (2004) \\
\hline & $\begin{array}{l}\text { Adverse systemic reactions to treatment of } \\
\text { onchocerciasis with ivermectin at normal and } \\
\text { high doses given annually or three-monthly }\end{array}$ & None & Kamgno et al. (2004) \\
\hline & $\begin{array}{l}\text { A randomized, double-blind, controlled trial } \\
\text { of the effects of ivermectin at normal and } \\
\text { high doses, given annually or three-monthly, } \\
\text { against } O \text {. volvulus: ophthalmological results }\end{array}$ & NCT02511353 & Fobi et al. (2005) \\
\hline & $\begin{array}{l}\text { Chemokines in onchocerciasis patients after a } \\
\text { single dose of ivermectin }\end{array}$ & None & Fendt et al. (2005) \\
\hline
\end{tabular}


Table 1 (continued)

\begin{tabular}{|c|c|c|c|}
\hline Drug name & Study title & Clinical trial identifier & Reference \\
\hline & $\begin{array}{l}\text { Evidence for macrofilaricidal activity of iver- } \\
\text { mectin against female Onchocerca volvulus: } \\
\text { further analysis of a clinical trial in the Repub- } \\
\text { lic of Cameroon indicating two distinct killing } \\
\text { mechanisms }\end{array}$ & None & Duke (2005) \\
\hline & $\begin{array}{l}\text { Non-adherence to community directed treatment } \\
\text { with ivermectin for onchocerciasis control in } \\
\text { Rungwe district, southwest Tanzania }\end{array}$ & None & Lakwo and Gasarasi. (2006) \\
\hline & Ivermectin dose assessment without weighing scales & None & Alexander et al. (1993) \\
\hline & $\begin{array}{l}\text { Individual host factors associated with Oncho- } \\
\text { cerca volvulus microfilarial densities } 15,80 \\
\text { and } 180 \text { days after a first dose of ivermectin }\end{array}$ & None & Pion et al. (2011) \\
\hline & $\begin{array}{l}\text { Sustainable control of onchocerciasis: ocular pathol- } \\
\text { ogy in onchocerciasis patients treated annually } \\
\text { with ivermectin for } 23 \text { years: a cohort study }\end{array}$ & PACTR201303000464219 & Banla et al. (2014) \\
\hline & $\begin{array}{l}\text { Macrofilaricidal efficacy of repeated doses of } \\
\text { ivermectin for the treatment of river blindness }\end{array}$ & None & Walker et al. (2017b) \\
\hline & $\begin{array}{l}\text { Safety and pharmacokinetic profile of fixed dose } \\
\text { ivermectin with an innovative } 18 \text {-mg tablet in } \\
\text { healthy adult volunteers }\end{array}$ & NCT03173742 & Muñoz et al. (2018) \\
\hline & $\begin{array}{l}\text { Single versus multiple dose ivermectin regi- } \\
\text { men in onchocerciasis-infected persons with } \\
\text { epilepsy treated with Phenobarbital: A } \\
\text { randomized clinical trial in the Democratic } \\
\text { Republic of Congo }\end{array}$ & NCT03052998 & Mandro et al. (2020) \\
\hline & $\begin{array}{l}\text { Ivermectin as an adjuvant to anti-epileptic treat- } \\
\text { ment in persons with onchocerciasis associ- } \\
\text { ated epilepsy: a randomized proof-of-concept } \\
\text { clinical trial }\end{array}$ & NCT03052998 & Mandro et al. (2020) \\
\hline & $\begin{array}{l}\text { Comparison of repeated doses of ivermectin } \\
\text { versus ivermectin plus albendazole for the } \\
\text { treatment of onchocerciasis: a randomized, } \\
\text { open-label, clinical trial }\end{array}$ & ISRCTN50035143 & Debrah et al. (2020) \\
\hline & $\begin{array}{l}\text { Safety and efficacy of IDA for onchocerciasis } \\
\text { (Dolf IDA/Oncho) }\end{array}$ & NCT04188301 & Study ongoing \\
\hline & $\begin{array}{l}\text { Efficacy of ivermectin and albendazole against } \\
\text { onchocerciasis in the Volta Region, Ghana }\end{array}$ & NCT02078024 & Study ongoing \\
\hline & $\begin{array}{l}\text { An open study of ivermectin at } 150 \mathrm{mcg} / \mathrm{kg} \\
\text { single dose, capsule formulation) for the treat- } \\
\text { ment of onchocerciasis in children } 6-13 \text { years } \\
\text { old. } 6 \text { months follow up }\end{array}$ & None & Not published \\
\hline
\end{tabular}


Table 1 (continued)

\begin{tabular}{|c|c|c|c|c|}
\hline & Drug name & Study title & Clinical trial identifier & Reference \\
\hline \multirow[t]{8}{*}{2} & \multirow[t]{8}{*}{ Moxidectin } & $\begin{array}{l}\text { The antiparasitic moxidectin: safety, tolerability, } \\
\text { and pharmacokinetics in humans }\end{array}$ & None & Cotreau et al. (2003) \\
\hline & & $\begin{array}{l}\text { Excretion of moxidectin into breast milk and } \\
\text { pharmacokinetics in healthy lactating women }\end{array}$ & None & Korth-Bradley et al. (2011) \\
\hline & & $\begin{array}{l}\text { Relative bioavailability of liquid and tablet for- } \\
\text { mulations of the antiparasitic moxidectin }\end{array}$ & None & Korth-Bradley et al. (2012) \\
\hline & & $\begin{array}{l}\text { A randomized, single-ascending-dose, } \\
\text { ivermectin-controlled, double-blind study of } \\
\text { moxidectin in Onchocerca volvulus infection }\end{array}$ & NCT00300768 & Awadzi et al. (2014) \\
\hline & & $\begin{array}{l}\text { Single dose moxidectin versus ivermectin for } \\
\text { Onchocerca volvulus infection in Ghana, } \\
\text { Liberia and the Democratic Republic of the } \\
\text { Congo; a randomized, controlled, double-blind } \\
\text { phase } 3 \text { trial }\end{array}$ & NCT00790998 & Opoku et al. (2018) \\
\hline & & $\begin{array}{l}\text { Safety of a single dose of moxidectin compared } \\
\text { with ivermectin in individuals living in oncho- } \\
\text { cerciasis endemic areas }\end{array}$ & NCT04311671 & Recruiting \\
\hline & & $\begin{array}{l}\text { Safety and efficacy of annual or biannual doses } \\
\text { of moxidectin or ivermectin for onchocerciasis }\end{array}$ & NCT03876262 & Recruiting \\
\hline & & $\begin{array}{l}\text { A pharmacokinetic and safety study of moxidec- } \\
\text { tin to identify an optimal dose for treatment of } \\
\text { children } 4 \text { to } 11 \text { years }\end{array}$ & NCT03962062 & Recruiting \\
\hline \multirow[t]{4}{*}{3} & \multirow[t]{4}{*}{ Emodepside } & $\begin{array}{l}\text { First in man clinical trial of emodepside (BAY } \\
44-4400 \text { ) }\end{array}$ & NCT02661178 & Gillon et al. (2021) \\
\hline & & $\begin{array}{l}\text { Safety, tolerability and pharmacokinetics of } \\
\text { emodepside, a potential novel treatment for } \\
\text { onchocerciasis (river blindness), in healthy } \\
\text { male subjects }\end{array}$ & NCT03383614 & Gillon et al. (2021) \\
\hline & & $\begin{array}{l}\text { Relative bioavailability study of emodepside } \\
\text { IR-tablets and solution }\end{array}$ & NCT03383523 & Not yet published \\
\hline & & $\begin{array}{l}\text { Emodepside phase II for the treatment of oncho- } \\
\text { cerciasis }\end{array}$ & PACTR202010898529928 & Not yet started \\
\hline \multirow[t]{2}{*}{4} & \multirow[t]{2}{*}{ Oxfendazole } & $\begin{array}{l}\text { Evaluating the safety and pharmacokinetics of } \\
\text { oxfendazole }\end{array}$ & NCT02234570 & An et al. (2019) \\
\hline & & $\begin{array}{l}\text { Pharmacokinetics, safety, and tolerability of } \\
\text { oxfendazole in healthy adults in an open-label } \\
\text { phase } 1 \text { multiple ascending dose and food } \\
\text { effect study }\end{array}$ & NCT03035760 & Bach et al. (2020) \\
\hline 5 & Auranofin & $\begin{array}{l}\text { Phase I trial: Phase I clinical trial results of } \\
\text { auranofin, a novel antiparasitic agent }\end{array}$ & NCT02089048 & Capparreli et al. (2016) \\
\hline
\end{tabular}


Table 1 (continued)

\begin{tabular}{|c|c|c|c|c|}
\hline & Drug name & Study title & Clinical trial identifier & Reference \\
\hline \multicolumn{5}{|c|}{ Indirect-acting drugs } \\
\hline \multirow[t]{11}{*}{6} & \multirow[t]{11}{*}{ Doxycycline } & $\begin{array}{l}\text { Endosymbiotic bacteria in worms as targets for } \\
\text { a novel chemotherapy in filariasis }\end{array}$ & None & Hoerauf et al. (2000) \\
\hline & & $\begin{array}{l}\text { Depletion of Wolbachia endobacteria in Oncho- } \\
\text { cerca volvulus by doxycycline and microfilari- } \\
\text { dermia after ivermectin treatment }\end{array}$ & None & Hoerauf et al. (2001) \\
\hline & & $\begin{array}{l}\text { Doxycycline in the treatment of human oncho- } \\
\text { cerciasis: kinetics of Wolbachia endobacteria } \\
\text { reduction and of inhibition of embryogenesis } \\
\text { in female Onchocerca worms }\end{array}$ & None & Hoerauf et al. (2003) \\
\hline & & $\begin{array}{l}\text { Wolbachia endobacteria depletion by doxycy- } \\
\text { cline as antifilarial therapy has macrofilari- } \\
\text { cidal activity in onchocerciasis: a randomized } \\
\text { placebo-controlled study }\end{array}$ & ISRCTN 71,141,922 & Hoerauf et al. (2008) \\
\hline & & $\begin{array}{l}\text { Effects of ivermectin with and without doxycy- } \\
\text { cline on clinical symptoms of onchocerciasis }\end{array}$ & None & Masud et al. (2009) \\
\hline & & $\begin{array}{l}\text { Community-directed delivery of doxycycline } \\
\text { for the treatment of onchocerciasis in areas of } \\
\text { co-endemicity with loiasis in Cameroon }\end{array}$ & None & Wanji et al. (2009) \\
\hline & & $\begin{array}{l}\text { Macrofilaricidal activity after doxycycline } \\
\text { only treatment of Onchocerca volvulus in an } \\
\text { area of Loa loa co-endemicity: a randomized } \\
\text { controlled trial }\end{array}$ & ISRCTN48118452 & Turner et al. (2010) \\
\hline & & $\begin{array}{l}\text { Long term impact of large scale community- } \\
\text { directed delivery of doxycycline for the treat- } \\
\text { ment of onchocerciasis }\end{array}$ & None & Tamarozzi et al. (2012) \\
\hline & & $\begin{array}{l}\text { Doxycycline leads to sterility and enhanced kill- } \\
\text { ing of female Onchocerca volvulus worms in } \\
\text { an area with persistent microfilaridermia after } \\
\text { repeated ivermectin treatment: a randomized, } \\
\text { placebo-controlled, double-blind trial }\end{array}$ & ISRCTN 66,649,839 & Debrah et al. (2015) \\
\hline & & $\begin{array}{l}\text { Comparison of doxycycline, minocycline, } \\
\text { doxycycline plus albendazole and albendazole } \\
\text { alone in their efficacy against onchocerciasis } \\
\text { in a randomized, open-label, pilot trial }\end{array}$ & ISRCTN 06,010,453 & $\begin{array}{l}\text { Klarmann-Schulz et al. } \\
\text { (2017) }\end{array}$ \\
\hline & & $\begin{array}{l}\text { Clinical trial of rifampin and azithromycin for } \\
\text { the treatment of river blindness }\end{array}$ & NCT00127504 & Not published \\
\hline \multirow[t]{2}{*}{7} & \multirow[t]{2}{*}{ Rifampicin } & $\begin{array}{l}\text { No depletion of Wolbachia from Onchocerca } \\
\text { volvulus after a short course of rifampin and/ } \\
\text { or azithromycin }\end{array}$ & None & Richards et al. (2007) \\
\hline & & $\begin{array}{l}\text { Efficacy of 2- and 4-week rifampicin treatment } \\
\text { on the Wolbachia of Onchocerca volvulus }\end{array}$ & None & Specht et al. (2008) \\
\hline 8 & $\begin{array}{l}\text { TylAMac } \\
\text { (ABBV- } \\
4083)\end{array}$ & $\begin{array}{l}\text { Study to assess adverse events, change in } \\
\text { disease activity and how oral ABBV- } 4083 \\
\text { capsules when given alone or in combination } \\
\text { with albendazole capsules moves in the body } \\
\text { of adult participants with Onchocerca volvulus } \\
\text { infection }\end{array}$ & NCT04913610 & Not yet started \\
\hline
\end{tabular}

*Used in the FDA registration package

The realization that a single yearly treatment with IVM could markedly limit transmission and pathology led to the decision by Merck \& Co. to donate the drug through the Mectizan Donation Program for MDA to control onchocerciasis. Current guidelines recommend annual (or biannual) treatment of every individual in targeted communities with an oral tablet of IVM (Mectizan), based on height. The current height-based IVM dosing has a range of 3-12 $\mathrm{mg}$ for four different height groups (90-119 cm, 120-140 cm, 141-158 cm and $>158 \mathrm{~cm}$ ). Children below $15 \mathrm{~kg}$ and visibly pregnant women are excluded from MDA (Crompton 2006). Recent 
meta-analysis further suggests that IVM is safe in children weighing less than $15 \mathrm{~kg}$ (Jittamala et al. 2021).

The recognition that SAEs, including coma and death, can occur in individuals harbouring high levels of $L$. loa microfilaremia who are treated with IVM (Boussinesq et al. 2003; Chesnais et al. 2020) has hindered the extension of MDA programs to loiasis endemic regions since individual diagnosis of $L$. loa microfilaremia using microscopic assays would have been required. A new strategy termed "Test and Not Treat" (TaNT), based on the use of the LoaScope to estimate $L$. loa microfilaraemia before treatment to exclude heavily infected patients, could allow safe implementation of MDA in loiasis endemic areas (Kamgno et al. 2017).

\section{Moxidectin}

Moxidectin belongs to the milbemycin family of antiparasitic endectocides, which were isolated in 1967 following fermentation of Streptomyces hygroscopes (a soil bacterium). In 1972, the 16-membered macrocyclic lactone structure of milbemycin was elucidated. In 1983, nemadectin (F-29249 $\alpha$ ), an active milbemycin product, was isolated from the fermentation of Streptomyces cyaneogriseus. Moxidectin was later chemically derived from nemadectin by the addition of a methoxime moiety at carbon 23 (Prichard and Geary 2019). The mechanism of action of moxidectin is thought to be similar to that of IVM, mediated through increased permeability of glutamate-gated chloride channels (GluCls) resulting in an influx of chloride ions and subsequent paralysis/death of the parasite (Wolstenholme et al. 2016). Treatment of mice with a single dose of moxidectin at 15 or $1.5 \mu \mathrm{g} / \mathrm{kg}$ resulted in mf reductions of $96 \%$ and $23 \%$, respectively. In contrast, a $48 \%$ reduction was observed with a single dose of $15 \mu \mathrm{g} / \mathrm{kg}$ IVM and a $2 \%$ increase with $1.5 \mu \mathrm{g} / \mathrm{kg}$ IVM/kg (Tagboto and Townson 1996). Moxidectin is minimally metabolized, has low affinity to p-glycoprotein transporters and shows an extended plasma half-life of 20-43 days in humans compared to IVM (Korth-Bradley et al. 2012; Prichard et al. 2012). This is because moxidectin is more lipophilic than IVM, which may result in greater retention in adipose tissue (Prichard et al. 2012). Moxidectin is effluxed by P-gp transporters at the blood-brain barrier (Kiki-Mvouaka et al. 2010), suggesting lower neurotoxicity for moxidectin compared to IVM, as recently observed in experimental animals (Janko and Geyer 2013). In people infected with $O$. volvulus, moxidectin was able to reduce and maintain low skin microfilarial density for longer than IVM (Awadzi et al. 2014). Also, moxidectin has been shown to have activity against human scabies (Mounsey et al. 2016).

Following a controlled, double-blind phase 3 trial conducted in Ghana, Liberia and the Democratic Republic of the Congo, moxidectin was registered for the treatment of onchocerciasis and is recognized as a highly efficacious microfilaricide (Opoku et al. 2018). If donated, this molecule could be an alternative to IVM in MDA programs (Milton et al. 2020). The Medicines Development for Global Health (MDGH) is currently starting recruitment for three clinical trials evaluating safety in a large patient cohort, paediatric dose-finding and comparison of moxidectin and IVM in annual and biannual dosing (see Table 1).

\section{Emodepside}

The semi-synthetic anthelminthic emodepside (synonyms: PF1022-221, BAY 44-4400 or bismorpholino-cyclooctadepsipeptide) and its parent fermentation product PF1022A are members of the $\mathrm{N}$-methylated cyclooctadepsipeptides, derived from a fungus (Rosellinia sp. PF1022). Emodepside is characterized by two morpholine rings in the para-position of each of the two (R)-phenyllactic acids, which increase solubility and improve the bioavailability of the compound compared to its natural precursor PF1022A (Harder et al. 2005). Emodepside is registered as a combination product with praziquantel (Profender ${ }^{\circledR}$ ) for the treatment of cats and dogs infected with, or at risk of, infection with nematodes and cestodes, and as a combination product with toltrazuril (Procox $\AA$ ) for the treatment of puppies with demonstrated or suspected infection with nematodes and coccidia.

Several targets have been suggested for the cyclooctadepsipeptides, with the voltage-gated, calcium-activated potassium channel SLO-1 as most likely candidate (Kulke et al. 2014). Additionally, the G-protein coupled receptor LAT-1 (Saeger et al. 2001) and ionotropic GABAA receptors (Chen et al. 1996; Miltsch et al. 2012) might contribute to susceptibility to cyclooctadepsipeptides.

Action on the SLO-1 K channel results in an inhibitory effect on motility, pharyngeal pumping and egg laying of nematodes. In addition to emodepside's success as a veterinary anthelminthic, several experiments showed its effect on filarial nematodes in various models, including initial studies on L. sigmodontis in Mastomys (Zahner et al. 2001) and recently $O$. ochengi in cattle (Bah et al. 2021). These experiments showed macrofilaricidal efficacy after 5 consecutive doses of $5-100 \mathrm{mg} / \mathrm{kg}$ in rodents and $0.75 \mathrm{mg} / \mathrm{kg}$ in cattle. Emodepside has a broad activity against different filarial species and stages including L3, L4, adult and $\mathrm{mf}$ of filarial parasites (reviewed in Krücken et al. 2021).

Emodepside is currently being evaluated for the treatment of human onchocerciasis within the scope of a drug development partnership between the Drugs for Neglected Diseases initiative (DND $i$ ) and Bayer AG (Krücken et al. 2021). Based on such promising results from preclinical studies, a phase I package (single and multiple ascending dose studies, food effect and relative bioavailability studies) was conducted in healthy volunteers (Gillon et al. 2021, Table 1). These studies showed that effective doses based on experiments in rodents and cattle can be reached in humans. 
Bayer AG has further developed a formulation with significantly improved biopharmaceutical properties and higher bioavailability compared to the conventional standard immediate release crystalline tablet (see Table 1). DND $i$ plans to start a proof-of-concept trial later in 2021 to determine the efficacy of emodepside in patients with onchocerciasis (see Table 1).

\section{Oxfendazole}

Oxfendadazole, [5-(phenylsulphinyl)-1H-benzimidazole2-yl] carbamic acid methyl ester, is a broad-spectrum benzimidazole anthelminthic used for veterinary practice against lungworms and enteric helminths in beef livestock. It has been established that benzimidazoles selectively bind with high affinity to parasite $\beta$-tubulin and inhibit microtubule polymerization, resulting in the destruction of cell structure and subsequent death of the parasite (Lacey 1990). Oxfendazole has gained much interest recently and is being repurposed for human use against tissue-dwelling larval helminths after demonstrating moderate macrofilaricidal activity in vitro against the adult stages of $O$. volvulus and Onchocerca gutturosa. In vivo oral treatment with oxfendazole for 5 days and 10 days in the murine Litomosoides sigmodontis model provided $100 \%$ macrofilaricidal clearance of the parasite and inhibited filarial embryogenesis in patent $L$. sigmodontis-infected jirds, respectively but had no direct effect on the mf (Hübner et al. 2020). Such an efficacy profile is desirable for MDA, because severe pathologies associated with dead microfilariae would be avoided.

As oxfendazole has broad antihelmintic activity through inhibition of tubulin polymerization, it is open for debate whether it should be evaluated as a potential drug against loiasis, a highly neglected NTD, targeting the adults but not the mf.

The human efficacious dose predicted by allometric scaling ranges from 1.5 to $4.1 \mathrm{mg} / \mathrm{kg}$ (Hübner et al. 2020). This dose has been proven to be safe in phase 1 clinical trials, including a multiple ascending dose study using five daily doses of 3, 7.5 and $15 \mathrm{mg} / \mathrm{kg}$ (Table 1) (Bach et al. 2020) and a single ascending dose phase 1 study in humans (An et al. 2019). DND $i$ has taken oxfendazole into their portfolio as a candidate for development for onchocerciasis (https://www. dndi.org/diseases-projects/portfolio/oxfendazole/). A bioavailability study to test the exposure of a tablet for field use is currently planned within the HELP consortium activities of the Horizon 2020/EU project (www.eliminateworms.org). The aim of the HELP consotrtium is to advance existing drug candidates along the development pipeline to fuel the empty anthelminthic drug pipeline for soil-transmitted helminths and onchocerciasis, joining expertise from both areas.

\section{Auranofin}

Auranofin $[2,3,4,6$-tetra- $o$-acetyl-L-thio- $\beta$-D-glycopyranpsato- $S$-(triethyl-phosphine)-gold] is an FDA-approved drug that was originally developed to treat rheumatoid arthritis in humans in 1985. Previous studies have shown that this drug is effective against several parasites; recently, Bulman et al. (2015) found that auranofin was effective in vitro in killing $O$. ochengi adult worms and in inhibiting the moulting of $O$. volvulus $\mathrm{L} 3 \mathrm{~s}$ with $\mathrm{IC}_{50}$ of 3 and $0.3 \mu \mathrm{M}$, respectively. The in vivo efficacy of auranofin was tested in gerbils infected with Brugia pahangi; a dosing regimen of $5 \mathrm{mg} / \mathrm{kg}$ bis in die (BID) on weekdays and semil in die (SID) on weekends was applied for 28 days (for a total of 48 doses). A $91 \%$ reduction of adult worm burden was observed in the auranofin-treated group compared to the control group. Evidence in several species of parasites suggests that thioredoxin reductase and a similar enzyme, thioredoxin glutathione reductase, are targeted by auranofin (Tejman-Yarden et al. 2013). Phase I first in human studies have been carried out and it has been shown to have a half-life $\left(t_{1 / 2}\right)$ of 35 days (Table 1$)$, meaning that steady-state blood levels could be reached in long-term therapy for onchocerciasis, a chronic disease (Capparelli et al; 2016).

\section{Flubendazole (FBZ)}

As a member of the benzimidazole anthelmintic class, FBZ is a tubulin inhibitor with aneugenic and embryotoxic effects like those observed with albendazole and other benzimidazole anthelmintics have been reported (Tweats et al. 2016; Longo et al. 2014). It has been shown in animal models and in a human trial (Dominguez-Vazquez et al., 1983) that parenterally administrated FBZ can attain $100 \%$ macrofilaricidal efficacy (Mackenzie and Geary, 2011). For decades, WHO and TDR have been advocating for the development of macrofilaricidal treatments for the elimination of onchocerciasis. This prompted the re-evaluation of FBZ as a potential macrofilaricide. However, because of its poor solubility and bioavailability, administration of FBZ via the oral route provides only marginal systemic exposure (Michiels et al. 1982). As parenteral administration of FBZ is not compatible with MDA programs, the initial goal of the project was to develop a new orally available formulation providing sufficient systemic exposure and high macrofilaricidal efficacy with short dosing regimens (Mackenzie and Geary 2011).

This aim was the driving force behind the decision by the Bill and Melinda Gates Foundation (BMGF) to fund preclinical development work with FBZ under the auspices of DND $i$, which led to the development of an amorphous solid dispersion (ASD) formulation first by AbbVie and then by Janssen Pharmaceutica. FBZ formulated as an ASD is orally bioavailable and was used for initial toxicological 
investigations (Longo et al. 2014; Tweats et al. 2016). Following encouraging in vivo efficacy results, Janssen Pharmaceutica further evaluated the orally available ASD formulation of FBZ and demonstrated macrofilaricidal in vivo efficacy (Fischer et al. 2019; Sjoberg et al. 2019; Hübner et al. 2019a, b). Despite these encouraging results, efficacious concentrations were associated with toxicity. Following consultation with FDA, Janssen Pharmaceutica decided to discontinue the development of FBZ because the risk-benefit ratio for patients was not considered to be favourable (Lachau-Durand et al. 2019).

\section{Indirect-acting drugs}

\section{Doxycycline}

Doxycycline is a broad-spectrum antibiotic belonging to the tetracycline family and is included in the World Health Organization's list of essential medicines (WHO 2019). It inhibits the production of bacterial proteins by binding to the $30 \mathrm{~S}$ ribosomal subunit, thus preventing the binding of transfer RNA to messenger RNA and further replication of the bacteria (Chopra and Roberts 2001). Bosshardt and colleagues were the first to show that tetracycline treatment of jirds infected with Brugia pahangi was able to inhibit the development of third-stage larvae into adult worms and the development of microfilaremia (Bosshardt et al. 1993). Many experiments followed, exploring the effect of Wolbachia depletion in various parasite/host combinations (Wan et al. 2019). Since doxycycline was already a registered tetracycline, it did not take long to conduct studies in humans infected with onchocerciasis, providing proof-of-concept for the therapeutic effect of Wolbachia depletion. Initially, a treatment of $100 \mathrm{mg} /$ day for 6 weeks was chosen, which resulted in the inhibition of microfilaridermia over the observation period of 18 months (Hoerauf et al. 2001). A number of studies followed, investigating other dose regimens (see Table 1). It is important to note that this indirect mode of action, via the inhibition of embryogenesis, results in a slow decline of $\mathrm{mf}$ in the infected human and prevents the adverse reactions (Mazzotti reaction) seen when there is a rapid reduction of $\mathrm{mf}$, for example after DEC treatment. It has been further argued that the absence of bacterial antigens per se avoids inflammatory reactions associated with the killing of macro- or microfilariae (Taylor et al. 2010).

There was clear evidence for the macrofilaricidal activity of doxycycline when longer follow-up time points (20-24 months) were chosen (Hoerauf et al. 2008). Doxycycline's mode of action allows its use in areas coendemic with Loiasis since Loa loa does not harbour Wolbachia (Grobusch et al, 2003). The use of doxycycline is, however, clearly contraindicated for large-scale treatment programs because of logistical challenges, the lengthy course of treatment (4-6 weeks), contraindications in children under 8 years and in pregnancy (Hoerauf et al. 2001). This gave the starting signal to setup the AWOL consortium (Taylor et al. 2014) to identify drugs and regimens that reduce the treatment period and which would be safe in currently excluded target populations (children and pregnant women) using a preclinical screening cascade developed by the consortium partners (Johnston et al. 2014; Specht et al. 2018) (see Table 1). Several promising results from either single treatments or combinations have been or are currently being, further explored, such as the new chemical entity TylAMac as well as registered drugs, such as minocycline and a rifampicin and moxifloxacin combination.

\section{Rifampicin}

Rifampicin is a semi-synthetic antibiotic produced from Streptomyces mediterranei. Its mechanism of action is through inhibition of DNA-dependent RNA polymerase activity by forming a stable complex with the enzyme, thus suppressing the initiation of RNA synthesis in Wolbachia (Campbell et al. 2001). The in vitro activity obtained in the Wolbachia-infected C6/36 cell (C6/36 wAlbB) assay for rifampicin exhibited an $\mathrm{EC}_{50}$ of $1.3 \mathrm{nM}$ (approximately 16.2fold more potent than doxycycline). The effect of rifampicin evaluated in SCID mice infected with Onchocerca ochengi and Brugia malayi showed a dose-dependent activity against Wolbachia. When administrated at $25 \mathrm{mg} / \mathrm{kg}$ bid for 7 days, rifampicin displayed significantly superior anti-Wolbachia activity against Brugia malayi compared to a 4-week doxycycline treatment at the same dose (Aljayyoussi et al. 2017).

Rifampicin was administrated for 14 days daily at $50 \mathrm{mg} / \mathrm{kg}$ orally to BALB/c mice infected with the rodent filaria, Litomosoides sigmodontis, and compared to doxycycline administrated orally at $25 \mathrm{mg} / \mathrm{kg}$ for 21 days. Depletion of endobacteria was observed following treatment with rifampicin but not following treatment with doxycycline. Furthermore, treatment with rifampicin resulted in a significant reduction in filarial survival, size and fertility (Volkmann et al. 2003). However, clinical studies in humans have shown that rifampicin $10 \mathrm{mg} / \mathrm{kg} / \mathrm{day}$ administered for 2 or 4 weeks has an inferior activity to 6-week doxycycline in onchocerciasis (Specht et al. 2008; Richards et al. 2007).

In SCID mice, a dose of $35 \mathrm{mg} / \mathrm{kg}$ administrated for 14-days elicits a reduction in Wolbachia above 90\%. Using pharmacokinetic/pharmacodynamic modelling, this dosing regimen corresponds to a human equivalent dose of $30-40 \mathrm{mg} / \mathrm{kg}$. It has been suggested that this clinical dosing regimen could be effective for the treatment of onchocerciasis (Aljayyoussi et al. 2017). 


\section{TylAMac (ABBV-4083)}

The discovery of ABBV-4083 began with the screening of a representative set of the AbbVie antibiotics collection (129 compounds). This focused library was tested against Wolbachia pipientis in an insect cell line within the AWOL consortium. From this screen, Tylosin A (TylA), a commercial veterinary macrolide antibiotic, was identified as novel lead. TylA is a macrolide antibiotic that is active mostly against Gram-positive bacteria and mycoplasmas by binding to the 50S ribosomal subunit, inhibiting protein synthesis (Risch et al. 2021). TylA has displayed potent anti-Wolbachia activity with an in vitro $\mathrm{EC}_{50}$ of $28 \mathrm{nM}$, but TylA is characterized by poor oral bioavailability resulting from low permeability $\left(<0.1 \cdot 10^{-6} \mathrm{~cm} / \mathrm{s}\right)$ in a canine kidney cell monolayer system (MDR-MDCK). Therefore, improving drug absorption by increasing permeability became a primary goal for lead optimization. Derivatization of the 4"-OH group of TylA (on the mycaminose sugar) was carried out by AbbVie to improve oral absorption while simultaneously increasing anti-Wolbachia potency. Further optimization of this substituent led to the development of ABBV-4083, the 4"-(4F-benzyl) stable analogue, which is very active against Wolbachia, with an improved pharmacokinetic profile. ABBV-4083 was evaluated in gerbils orally at $150 \mathrm{mg} / \mathrm{kg}$, once daily for 14 days. Even 16 weeks post-treatment initiation (PTI), Wolbachia levels remained reduced by $>99.9 \%$ in the female adult worms recovered from the host animals. Furthermore, 7 weeks PTI, levels of circulating microfilariae declined and were completely cleared from 12 weeks PTI (von Geldern et al. 2019). The efficacy of A-1574083 (now called ABBV4083) was tested in mouse and gerbil infection models of lymphatic filariasis (Brugia malayi and Litomosoides sigmodontis) and onchocerciasis (Onchocerca ochengi). A 1- or 2-week course of oral A-1574083 provided $>90 \%$ Wolbachia depletion from nematodes in infected animals, resulting in a block in embryogenesis and depletion of microfilarial worm loads with superior efficacy compared to a 3- to 4-week course of doxycycline or minocycline (Taylor et al. 2019) (Table 2). Following completion of regulatory enabling studies and first in human clinical trials, DND $i$ is currently preparing a proof-of-concept trial later in 2021 to determine the efficacy of ABBV-4083 in onchocerciasis patients.

\section{AWZ-1066S}

To identify novel anti-Wolbachia chemotypes, 10,000 compounds selected from a commercial library were screened using a phenotypic cell-based screen incorporating a Wolbachia-infected cell line. Identified hits were optimized for both anti-Wolbachia activity and drug metabolism/pharmacokinetic (DMPK) properties. The core of one of the identified hits was thienopyrimidine. Optimization of this starting hit molecule led to AWB158 with a quinazoline core, which was further optimized into AWZ1066 with an azaquinazoline core. These modifications have resolved the metabolic stability associated with the original core while improving potency against Wolbachia. AWZ1066 has two enantiomers, namely AWZ1066S and AWZ1066R. The (S)-isomer is more potent compared to the (R)-isomer both in in vitro antiWolbachia assays $\left(\mathrm{EC}_{50}=2.5 \pm 0.4\right.$ vs. $\left.14.4 \pm 3.7 \mathrm{nM}\right)$ and in a microfilaria assay (121 vs. $408 \mathrm{nM}$ ). AWZ1066 (racemic mixture) was active against Wolbachia (Clare et al. 2015) with an $\mathrm{EC}_{50}$ of $2.6 \pm 0.5 \mathrm{nM}$. Despite being a mammalian P-gp transporter substrate (i.e. it is pumped out of the cell to be eliminated), AWZ1066S showed good oral bioavailability (range 54 to $91 \%$ ) across a range of dosages up to $250 \mathrm{mg} /$ $\mathrm{kg}$ in Brugia malayi SCID CB.17 mice and gebril model. Treatment with AWZ1066S administrated twice-daily at 100 and $50 \mathrm{mg} / \mathrm{kg}$ orally for 7 days in a Litomosoides sigmodontis gerbil model was investigated. The Wolbachia load was reduced by $>99 \%$ compared to the untreated group. Fourteen weeks post-treatment, microfilaremia was inhibited in treated animals. AWZ1066S also has a faster kill rate compared with other known antibiotics tested against Wolbachia in vitro and its mode of action is by inhibition of protein synthesis. AWZ1066S can achieve maximum reduction of Wolbachia just after 1 day of drug exposure compared with the other antibiotics tested (1 to 6 days of exposure) (Hong et al. 2019). A global health innovative fund has been awarded for the development of AWZ1066S, a small molecule anti-Wolbachia candidate macrofilaricide drug (https:// www.prnewswire.com/news/global-health-innovative-techn ology-\%28ghit\%29-fund/).

\section{Corallopyronin A}

Corallopyronin A (CorA) is a natural compound originally isolated from the myxobacterial strain Corallococcus coralloides $\mathrm{c} 127$, representing a new structural type of antibiotic having a pyrone ring conferring rigidity to the central part of the molecule with two chains attached to the ring. One side of the chain carries a terminal vinyl carbamate functionality, while the other is characterized by several double bonds and a hydroxyl group (Schiefer et al. 2012). Both groups interact with the bacterial enzyme RNA polymerase (RNAP), preventing the correct interaction with the DNA template (Belogurov et al. 2009). Because the site and mode of action of CorA are different from that of rifampicin, CorA has activity against rifampicin-resistant $S$. aureus (O'Neill et al. 2000). Eukaryotic RNAP is resistant to CorA (Irschik et al. 1985), making this antibiotic attractive for further studies.

Using the C6/36 cell line from Aedes albopictus infected with Wolbachia pipientis, CorA depleted Wolbachia in a dosedependent manner, and $1 \mu \mathrm{g} / \mathrm{mL}(1.895 \mu \mathrm{M})$ of Cor depleted the endobacteria from the cells to levels equivalent to those 


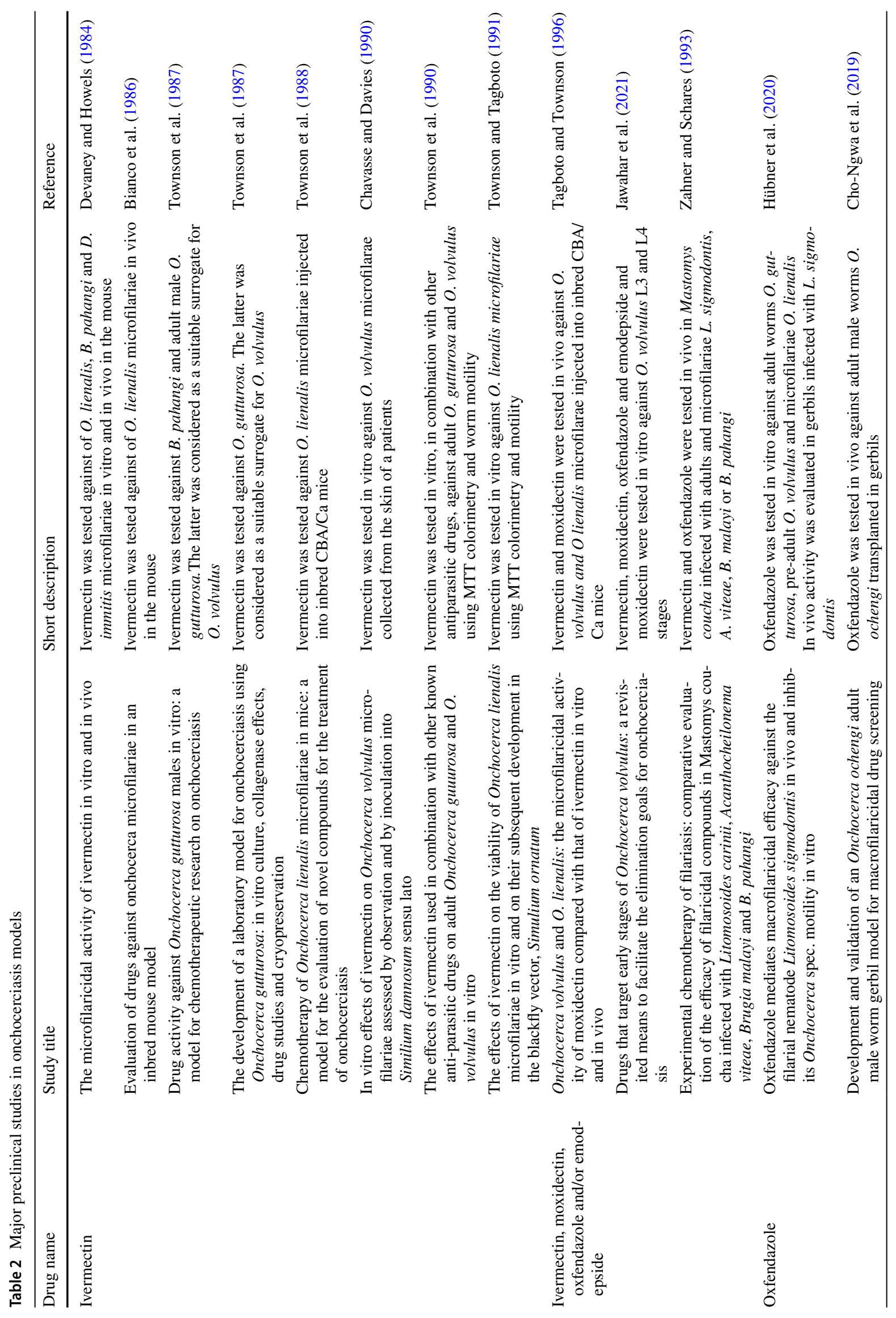




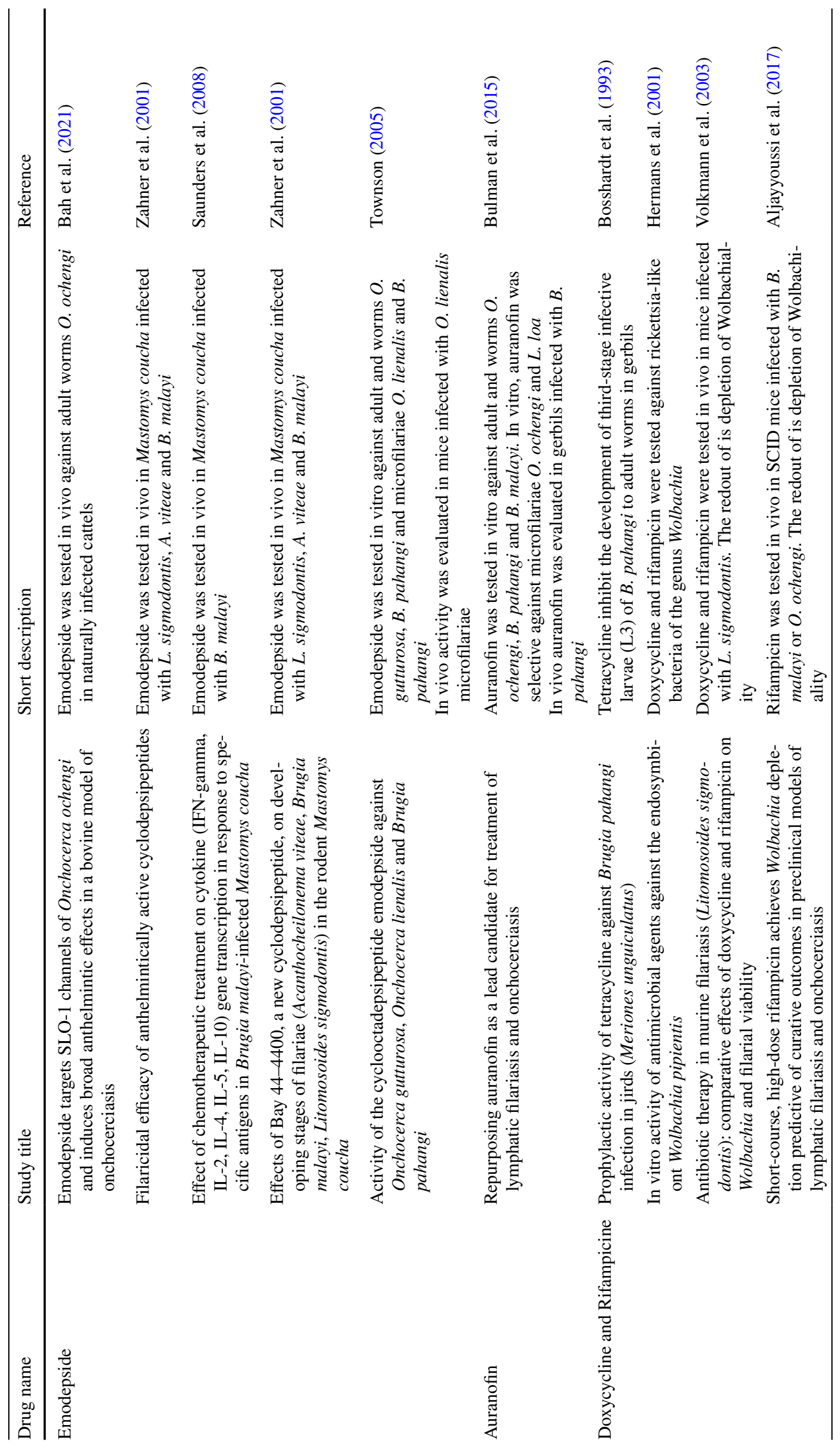




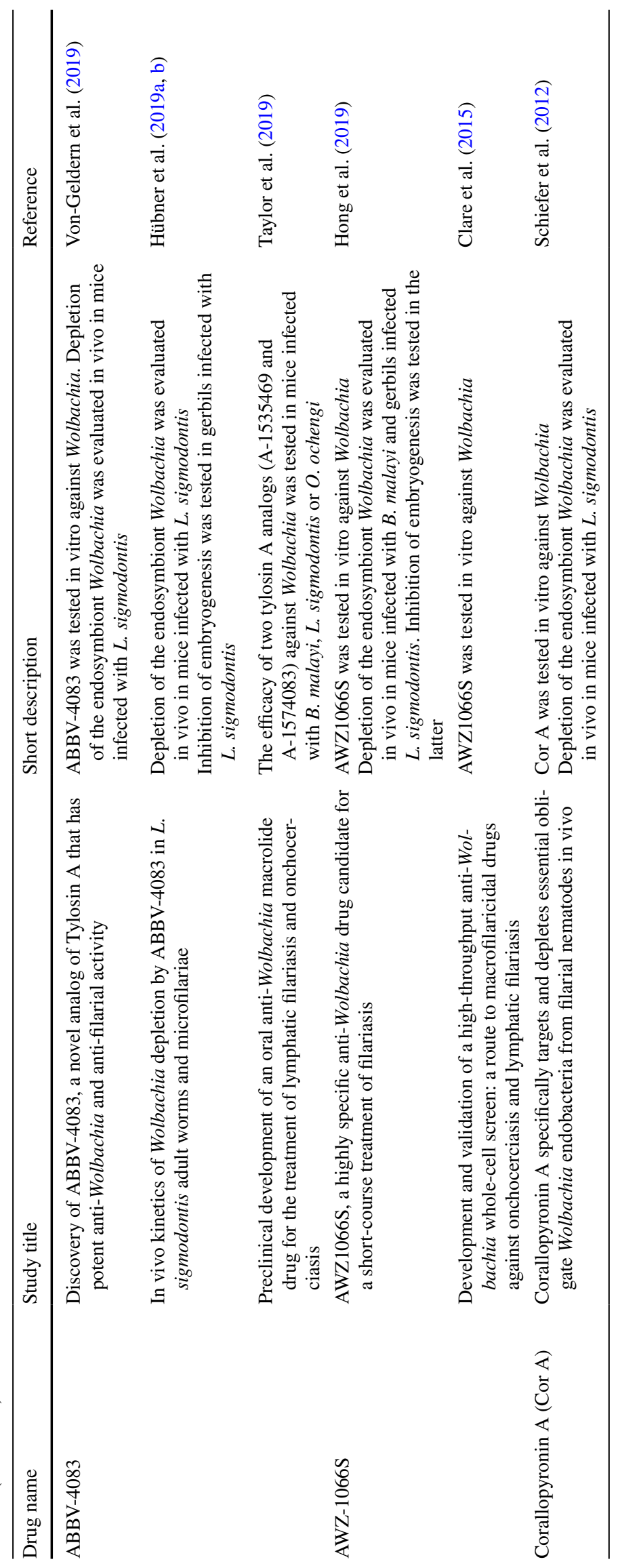


of $4 \mu \mathrm{g} / \mathrm{mL}(7.8 \mu \mathrm{M})$ doxycycline and $0.1 \mu \mathrm{g} / \mathrm{mL}(121.5 \mathrm{nM})$ rifampicin. Assessment of 4-week treatment of $35 \mathrm{mg} / \mathrm{kg} / \mathrm{day}$ CorA in mice infected with $L$. sigmodontis showed a blockage of worm development at the L4 stage and thus reduced worm length, sustained microfilaria clearance and inhibited embryogenesis; CorA showed macrofilaricidal efficacy during chronic filarial infection (Schiefer et al. 2012). A combination therapy of CorA and albendazole further enhanced the macrofilaricidal efficacy, with a shortened treatment regimen of 7 , 10 and 14 days at a CorA dose as low as $10 \mathrm{mg} / \mathrm{kg}$. This is the first anti-wolbachial treatment that has been able to achieve robust macrofilaricidal efficacy in the L. sigmodontis model (Schiefer et al. 2020). CorA is being developed for clinical phase 1 trials within the German Center for Infection Research (https://www.dzif.de/en/corallopyronin-new-antibiotic-again st-worm-infections) and the HELP consortium within Horizon 2020/EU (www.eliminateworms.org).

\section{Conclusion}

It is worth noting that programs have made tremendous efforts towards the control of onchocerciasis using IVM as the sole prophylactic microfilaricidal therapy. For elimination to be achieved at a faster rate, suitable, safe and cost-effective macrofilaricides must be developed, and this is one of the top priority goals of the Drugs for Neglected Diseases initiative, which is developing emodepside, tylamac and oxfendazole. These potential macrofilaricides will help to interrupt the parasite life cycle, thus preventing the adult females from producing young larvae. However, drug development is handicapped by high attrition rates, and many promising molecules fail during preclinical development or in subsequent toxicological, safety and efficacy testing; thus, $R \& D$ costs in the aggregate are very high. The level of investment into R\&D for new products for NTDs, as reported in the annual Global Funding of Innovation for Neglected Diseases (G-FINDER) surveys, shows that few NTD areas receive anywhere near the level of funding required and that funding, when it is available, is rarely allocated in a manner likely to move products through the pipeline to patients. Therefore, no dedicated drug development pipeline for human filariasis is in place and it is essential that stakeholders, funders, industry, academics and NGOs adopt a cooperative approach and share the responsibility to reduce risks and overcome these obstacles. Joint efforts are being made to cut the cost of R\&D for new drugs for NTDs and increase the attractiveness of this sector to funders and investors. Supportive programs by the FDA (priority voucher program: https://www.fda.gov/about-fda/ center-drug-evaluation-and-research-cder/tropical-disea se-priority-review-voucher-program) and EMA (article 58: https://www.ema.europa.eu/en/human-regulatory/marketingauthorisation/medicines-use-outside-european-union) aim to increase incentives for companies to engage in drug development for NTDs. Furthermore, The 2012 London declaration (https://unitingtocombatntds.org/london-declaration-negle cted-tropical-diseases/) united pharmaceutical companies, donors, endemic countries and non-government organizations in the recognition that new drugs need to be developed to achieve the elimination goals. The signatories of the London Declaration made a clear statement that it is important to take the initiative now for the development of new drugs to avoid a scenario in 2030, when elimination targets may not be achieved and valuable time wasted. Joint efforts such as in product development partnerships are necessary to achieve this goal. The result of such collaboration with pharmaceutical companies has led to the development of emodepside (Bayer AG, Bayer Animal Health; Krücken et al. 2021) and ABBV-4083 (AbbVie; Kempf and Marsh, 2020).

Author contributions All authors contributed to the manuscript outline and manuscript writing.

Funding Adela Ngwewondo is a current holder of a WHO/TDR Clinical Research and Development Fellowship.

Data availability Not applicable.

\section{Declarations}

Ethics approval Not applicable.

Consent to participate Not applicable.

Consent for publication Not applicable for this article.

Conflict of interest The authors declare no competing interests.

Open Access This article is licensed under a Creative Commons Attribution 4.0 International License, which permits use, sharing, adaptation, distribution and reproduction in any medium or format, as long as you give appropriate credit to the original author(s) and the source, provide a link to the Creative Commons licence, and indicate if changes were made. The images or other third party material in this article are included in the article's Creative Commons licence, unless indicated otherwise in a credit line to the material. If material is not included in the article's Creative Commons licence and your intended use is not permitted by statutory regulation or exceeds the permitted use, you will need to obtain permission directly from the copyright holder. To view a copy of this licence, visit http://creativecommons.org/licenses/by/4.0/.

\section{References}

Abiose A, Jones BR, Cousens SN, Murdoch I, Cassels-Brown A, Babalola OE, Alexander ND, Nuhu I, Evans J, Ibrahim UF, Mahmood AO (1993) Reduction in incidence of optic nerve disease with annual ivermectin to control onchocerciasis. Lancet 341(8838):130-134. https://doi.org/10.1016/0140-6736(93)90002-x 
Alexander ND, Cousens SN, Yahaya H, Abiose A, Jones BR (1993) Ivermectin dose assessment without weighing scales. Bull World Health Organ 71(3-4):361-6

Ali MM, Mukhtar MM, Baraka OZ, Homeida MM, Kheir MM, Mackenzie CD (2002) Immunocompetence may be important in the effectiveness of Mectizan (ivermectin) in the treatment of human onchocerciasis. Acta Trop 84(1):49-53. https://doi.org/10.1016/ s0001-706x(02)00117-1

Aljayyoussi G, Tyrer HE, Ford L, Sjoberg H, Pionnier N, Waterhouse D, Davies J, Gamble J, Metuge H, Cook D, Steven A, Sharma R, Guimaraes AF, Clare RH, Cassidy A, Johnston KL, Myhill L, Hayward L, Wanji S, Turner JD, Taylor MJ, Ward SA (2017) Short-course, high-dose rifampicin achieves Wolbachia depletion predictive of curative outcomes in preclinical models of lymphatic filariasis and onchocerciasis. Sci Rep 7(1):210. https:// doi.org/10.1038/s41598-017-00322-5

An G, Murry DJ, Gajurel K, Bach T, Deye G, Stebounova LV, Codd EE, Horton J, Gonzalez AE, Garcia HH, Ince D, HodgsonZingman D, Nomicos EYH, Conrad T, Kennedy J, Jones W, Gilman RH, Winokur P (2019) Pharmacokinetics, safety, and tolerability of oxfendazole in healthy volunteers: a randomized, placebo-controlled first-in-human single-dose escalation study. Antimicrob Agents Chemother 63(4):e02255-e2318. https://doi. org/10.1128/AAC.02255-18

Awadzi K, Dadzie KY, Shulz-Key H, Haddock DR, Gilles HM, Aziz MA (1985) The chemotherapy of onchocerciasis X. An assessment of four single dose treatment regimes of MK-933 (ivermectin) in human onchocerciasis. Ann Trop Med Parasitol 79(1):63-78

Awadzi K, Dadzie KY, Schulz-Key H, Gilles HM, Fulford AJ, Aziz MA (1986) The chemo therapy of onchocerciasis. XI. A doubleblind comparative study of ivermectin, diethylcarbamazine and placebo in human onchocerciasis in northern Ghana. Ann Trop Med Parasitol 80(4):433-42. https://doi.org/10.1080/00034983. 1986.11812044

Awadzi K, Dadzie KY, Kläger S, Gilles HM (1989) The chemotherapy of onchocerciasis. XIII. Studies with ivermectin in onchocerciasis patients in northern Ghana, a region with long lasting vector control. Trop Med Parasitol 40(3):361-6

Awadzi K, Opoku NO, Addy ET, Quartey BT (1995) The chemotherapy of onchocerciasis. XIX: The clinical and laboratory tolerance of high dose ivermectin. Trop Med Parasitol 46(2):131-7

Awadzi K, Attah SK, Addy ET, Opoku NO, Quartey BT (1999) The effects of high-dose iver mectin regimens on Onchocerca volvulus in onchocerciasis patients. Trans R Soc Trop Med Hyg 93(2):189-194. https://doi.org/10.1016/s0035-9203(99)90305-x

Awadzi K, Gilles HM (1992) Diethylcarbamazine in the treatment of patients with onchocerciasis. BrJ Clin Pharmacol 34(4):281-288. https://doi.org/10.1111/j.1365-2125.1992.tb05632.x

Awadzi K, Attah SK, Addy ET, Opoku NO, Quarty BT (2004) Thirtymonth follow up of sub-optimal responders to multiple treatments with ivermectin, in two onchocerciasis endemic foci in Ghana. Ann Trop Med Parasitol 98:359-370

Awadzi K, Opoku NO, Attah SK, Lazdins-Helds J, Kuesel AC (2014) A randomized, single-ascending-dose, ivermectin-controlled, double-blind study of moxidectin in Onchocerca volvulus infection. PLoS Negl Trop Dis 8:e2953. https://doi.org/10.1371/journ al.pntd.0002953

Aziz MA, Diallo S, Diop IM, Lariviere M, Porta M (1982) Efficacy and tolerance of ivermectin in human onchocerciasis. Lancet 2(8291):171-173. https://doi.org/10.1016/s0140-6736(82) 91026-1

Bach T, Galbiati S, Kennedy JK, Deye G, Nomicos EYH, Codd EE, Garcia HH, Horton J, Gilman RH, Gonzalez AE, Winokur P, An G (2020) Pharmacokinetics, safety, and tolerability of oxfendazole in healthy adults in an open-label phase 1 multiple ascending dose and food effect study. Antimicrob Agents Chemother 64(11):e01018-e1020. https://doi.org/10.1128/AAC.01018-20

Bah GS, Schneckener S, Hahnel SR, Bayang NH, Fieseler H, Schmuck GM, Krebber R, Sarr A, Terjung C, Ngangyung HF, Ekale DD, Mfopit YM, Rufener L, Graham-Brown J, Tanya V, GlenschekSieberth M, Kulke D, Makepeace BL (2021) Emodepside targets SLO-1 channels of Onchocerca ochengi and induces broad anthelmintic effects in a bovine model of onchocerciasis. PLoS Pathog 17(6):e1009601. https://doi.org/10.1371/journal.ppat. 1009601

Banla M, Tchalim S, Karabou PK, Gantin RG, Agba AI, Kére-Banla A, Helling-Giese G, Heuschkel C, Schulz-Key H, Soboslay PT (2014) Sustainable control of onchocerciasis: ocular pathology in onchocerciasis patients treated annually with ivermectin for 23 years: a cohort study. PLoS ONE 9(6):e98411. https://doi.org/ 10.1371/journal.pone.0098411

Basset D, Bouree P, Basset A, Lariviere M (1989) Effets de la diéthylcarbamazine et de l'ivermectine sur la mobilisation des microfilaires d'Onchocerca volvulus [Effects of diethylcarbamazine and ivermectin on the mobilization of microfilariae of Onchocerca volvulus]. Pathol Biol (Paris) 37(5 Pt 2):668-72 (French)

Belogurov GA, Vassylyeva MN, Sevostyanova A, Appleman JR, Xiang AX, Lira R, Webber SE, Klyuyev S, Nudler E, Artsimovitch I, Vassylyev DG (2009) Transcription inactivation through local refolding of the RNA polymerase structure. Nature 457(7227):332-335. https://doi.org/10.1038/nature07510

Bianco AE, Nwachukwu MA, Townson S, Doenhoff MJ, Muller RL (1986) Evaluation of drugs against onchocerca microfilariae in an inbred mouse model. Trop Med Parasitol 37:39-45

Bosshardt SC, McCall JW, Coleman SU, Jones KL, Petit TA, Klei TR (1993) Prophylactic activity of tetracyclineagainst Brugia pahangiinfection in jirds (Meriones unguiculatus). J Parasitol 79:775-777

Boussinesq M, Chippaux JP (2001) A controlled prospective trial of the prophylactic effect of a single dose of ivermectin against Onchocerca volvulus. Parasite 8(3):255-259. https://doi.org/10. 1051/parasite/2001083255

Boussinesq M, Gardon J, Gardon-Wendel N, Chippaux JP (2003) Clinical picture, epidemio logy and outcome of Loa-associated serious adverse events related to mass ivermectin treatment of onchocerciasis in Cameroon. Filaria J 2(Suppl 1):S4. https://doi.org/10. 1186/1475-2883-2-S1-S4

Boussinesq M, Fobi G, Kuesel AC (2018) Alternative treatment strategies to accelerate the elimination of onchocerciasis. Int Health 10:i40-i48. https://doi.org/10.1093/inthealth/ihx054

Brieger WR, Awedoba AK, Eneanya CI, Hagan M, Ogbuagu KF, Okello DO, Ososanya OO, Ovuga EB, Noma M, Kale OO, Burnham GM, Remme JH (1998) The effects of ivermectin on onchocercal skin disease and severe itching: results of a multicentre trial. Trop Med Int Health 3(12):951-961. https://doi.org/ 10.1046/j.1365-3156.1998.00339.x

Budden FH (1976) The natural history of ocular onchocerciasis over a period of 14-15 years and the effect on this of a single course of suramin therapy. Trans R Soc Trop Med Hyg 70(5-6):484-491. https://doi.org/10.1016/0035-9203(76)90134-6

Bulman CA, Bidlow CM, Lustigman S, Cho- Ngwa F, Williams D, Rascón AA Jr, Tricoche N, Samje M, Bell A, Suzuki B, Lim KC, Supakorndej N, Supakorndej P, Wolfe AR, Knudsen GM, Chen S, Wilson C, Ang KH, Arkin M, Gut J, Franklin C, Marcellino C, McKerrow JH, Debnath A, Sakanari JA (2015) Repurposing auranofin as a lead candidate for treatment of lymphatic filariasis and onchocerciasis. PLoS Negl Trop Dis 9(2):e0003534. https:// doi.org/10.1371/journal.pntd.0003534

Burnham GM (1993) Adverse reactions to ivermectin treatment for onchocerciasis. Results of a placebo-controlled, double-blind 
trial in Malawi. Trans R Soc Trop Med Hyg 87(3):313-7. https:// doi.org/10.1016/0035-9203(93)90144-f

Burnham G (1995) Ivermectin treatment of onchocercal skin lesions: observations from a placebo-controlled, double-blind trial in Malawi. Am J Trop Med Hyg 52(3):270-276. https://doi.org/ 10.4269/ajtmh.52-270

Burnham G (1998) Onchocerciasis. Lancet 351:1341-1346

Campbell WC (1983) Progress and prospects in the chemotherapy of nematode infections of man and other animals. J Nematol 15:608-615

Campbell EA, Korzheva N, Mustaev A, Murakami K, Nair S, Goldfarb A, Darst SA (2001) Structural mechanism for rifampicin inhibition of bacterial RNA polymerase. Cell 104(6):901-912. https:// doi.org/10.1016/s0092-8674(01)00286-0

Capparelli EV, Bricker-Ford R, Rogers MJ, McKerrow JH, Reed SL (2016) Phase I clinical trial results of auranofin, a novel antiparasitic agent. Antimicrob Agents Chemother 61(1):e01947-e2016. https://doi.org/10.1128/AAC.01947-16

Chavasse DC, Davies JB (1990) In vitro effects of ivermectin on Onchocerca volvulus microfilariae assessed by observation and by inoculation into Similium damnosum sensu lato. Trans R Soc Trop Med Hyg 84:707-708

Chavasse DC, Post RJ, Lemoh PA, Whitworth JA (1992) The effect of repeated doses of ivermectin on adult female Onchocerca volvulus in Sierra Leone. Trop Med Parasitol 43(4):256-262

Chen W, Terada M, Cheng JT (1996) Characterization of subtypes of gammaaminobutyric acid receptors in an Ascaris muscle preparation by binding assay and binding of PF1022A, a new anthelmintic, on the receptors. Parasitol Res 82:97-101

Chesnais CB, Pion SD, Boulle C, Gardon J et al (2020) Individual risk of post-ivermectin serious adverse events in subjects infected with Loa loa. EClinMed 28:100582

Chippaux JP, Boussinesq M, Fobi G, Lafleur C, Audugé A, Banos MT, Ngosso A, Prod'hon J (1999) Effect of repeated ivermectin treatments on ocular onchocerciasis: evaluation after six to eight doses. Ophthalmic Epidemiol 6(4):229-246. https://doi.org/10. 1076/opep.6.4.229.4185

Chopra I, Roberts M (2001) Tetracycline antibiotics: mode of action, applications, molecular biology, and epidemiology of bacterial resistance. Microbiol Mol Biol Rev 65(2):232-260

Cho-Ngwa F, Mbah GE, Ayiseh RB, Ndi EM, Monya E, Tumanjong IM et al (2019) Development and validation of an Onchocerca ochengi adult male worm gerbil model for macrofilaricidal drug screening. PLoS Negl Trop Dis 13(7):e0007556. https://doi.org/ 10.1371/journal.pntd.0007556

Churchill DR, Godfrey-Faussett P, Birley HD, Malin A, Davidson RN, Bryceson AD (1994) A trial of a three-dose regimen of ivermectin for the treatment of patients with onchocerciasis in the UK. Trans R Soc Trop Med Hyg 88(2):242. https://doi.org/10.1016/ 0035-9203(94)90315-8 (Erratum in: Trans R Soc Trop Med Hyg 1994 May-Jun;88(3):284)

Clare RH, Cook DA, Johnston KL, Ford L, Ward SA, Taylor MJ (2015) Development and validation of a high-throughput antiWolbachia whole-cell screen: a route to macrofilaricidal drugs against onchocerciasis and lymphatic filariasis. J Biomol Screen 20(1):64-69. https://doi.org/10.1177/1087057114551518

Coffeng LE, Stolk WA, Hoerauf A, Habbema D, Bakker R, Hopkins AD, deVlas SJ (2014) Elimination of African onchocerciasis: modelling the impact of increasing the frequency of ivermectin mass treatment. PLoS ONE 9:e115886. https://doi.org/10.1371/ journal.pone.0115886

Cousens SN, Cassels-Brown A, Murdoch I, Babalola OE, Jatau D, Alexander ND, Evans JE, Danboyi P, Abiose A, Jones BR (1997) Impact of annual dosing with ivermectin on progression of onchocercal visual field loss. Bull World Health Organ 75(3):229-36
Cotreau MM, Warren S, Ryan JL, Fleckenstein L, Vanapalli SR, Brown KR, Rock D, Chen CY, Schwertschlag US (2003) The antiparasitic moxidectin: safety, tolerability, and pharmacokinetics in humans. J Clin Pharmacol 43(10):1108-1115. https://doi.org/ $10.1177 / 0091270003257456$

Crompton DWT, World Health Organization (2006) Preventive chemotherapy in human helminthiasis: coordinated use of anthelminthic drugs in control interventions: a manual for health professionals and programme managers. World Health Organization, Geneva

Dadzie KY, Bird AC, Awadzi K et al (1987) Ocular findings in a double-blind study of ivermectin versus diethylcarbamazine versus placebo in the treatment of onchocerciasis. Br J Ophthalmol 71(2):78-85. https://doi.org/10.1136/bjo.71.2.78

Dadzie KY, Awadzi K, Bird AC, Schulz-Key H (1989) Ophthalmological results from a placebo controlled comparative 3-dose ivermectin study in the treatment of onchocerciasis. Trop Med Parasitol 40(3):355-360

De Sole G, Dadzie KY, Giese J, Remme J (1990) Lack of adverse reactions in ivermectin treatment of onchocerciasis. Lancet 335(8697):1106-1107. https://doi.org/10.1016/0140-6736(90) 92687-d

Debrah AY, Specht S, Klarmann-Schulz U, Batsa L, Mand S, MarfoDebrekyei Y, Fimmers R, Dubben B, Kwarteng A, Osei- Atweneboana M, Boakye D, Ricchiuto A, Büttner M, Adjei O, Mackenzie CD, Hoerauf A (2015) Doxycycline leads to sterility and enhanced killing of female Onchocerca volvulus worms in an area with persistent microfilaridermia after repeated ivermectin treatment: a randomized, placebo-controlled, double-blind trial. Clin Infect Dis 61(4):517-526. https://doi.org/10.1093/cid/ civ363

Debrah BL, Klarmann-Schulz U, Osei-Mensah J, Dubben B, Fischer K, Mubarik Y, Ayisi-Boateng NK, Ricchiuto A, Fimmers R, Konadu P, Nadal J, Gruetzmacher B, Weil G, Kazura JW, King CL, Debrah AY, Hoerauf A (2020) Comparison of repeated doses of ivermectin versus ivermectin plus albendazole for the treatment of onchocerciasis: a randomized, open-label, clinical trial. Clin Infect Dis 71(4):933-943. https://doi.org/10.1093/cid/ciz889

Devaney E, Howells RE (1984) The microfilaricidal activity of ivermectin in vitro and in vivo. Tropenrnedizin Und Parasitologie 35:47-49

Diallo S, Larivière M, Diop Mar I, N'Dir O, N'Diaye R, Badiane S, Porta M, Aziz M (1984) Conduite au Sénégal des premières études d'efficacité et de tolérance de l'ivermectine (MK 933) dans l'onchocercose humaine [Management in Senegal of the 1 st efficacy and tolerability studies of ivermectin (MK 933) in human onchocerciasis]. Bull Soc Pathol Exot Filiales 77(2):196205 (French)

Diallo S, Aziz MA, Lariviere M, Diallo JS, Diop-Mar I, N'Dir O, Badiane S, PY D, Schulz-Key H, Gazotte P, Victorius A, (1986) A double-blind comparison of the efficacy and safety of ivermectin and diethylcarbamazine in a placebo-controlled study of Senegalese patients with onchocerciasis. Trans Roy Soc Trop Med Hyg 80(6):927-934. https://doi.org/10.1016/0035-9203(86)90262-2

Dominguez-Vazquez A, Taylor HR, Greene BM, Ruvalcaba-Macias AM, Rivas-Alcala AR, Murphy RP, Beltran-Hernandez F (1983) Comparison of flubendazole and diethylcarbamazine in treatment of onchocerciasis. Lancet 1(8317):139-143. https://doi.org/10. 1016/s0140-6736(83)92753-8

Ducorps M, Gardon-Wendel N, Ranque S, Ndong W, Boussinesq M, Gardon J, Schneider D, Chippaux JP (1995) Effets secondaires du traitement de la loase hypermicrofilarémique par l'ivermectine [Secondary effects of the treatment of hypermicrofilaremic loiasis using ivermectin]. Bull Soc Pathol Exot 88(3):105-12 (French) 
Duke BO (1968) The effects of drugs on Onchocerca volvulus trials of suramin at different dosages and a comparison of the brands Antrypol, Moranyl and Naganol. Bull World Health Organ. 39(2):157-67

Duke BO, Zea-Flores G, Castro J, Cupp EW, Muñoz B (1990) Effects of multiple monthly doses of ivermectin on adult Onchocerca volvulus. Am J Trop Med Hyg 43(6):657-664. https://doi.org/ 10.4269/ajtmh.1990.43.657

Duke BO, Pacqué MC, Muñoz B, Greene BM, Taylor HR (1991a) Viability of adult Onchocerca volvulus after six 2-weekly doses of ivermectin. Bull World Health Organ 69(2):163-8

Duke BO, Zea-Flores G, Castro J, Cupp EW, Munoz B (1991b) Comparison of the effects of a single dose and of four six-monthly doses of ivermectin on adult Onchocerca volvulus. Am J Trop Med Hyg 45(1):132-137. https://doi.org/10.4269/ajtmh.1991. 45.132

Duke BO, Zea-Flores G, Castro J, Cupp EW, Munoz B (1992) Effects of three-month doses of ivermectin on adult Onchocerca volvulus. Am J Trop Med Hyg 46(2):189-194. https://doi.org/10. 4269/ajtmh.1992.46.189

Duke BO (2005) Evidence for macrofilaricidal activity of ivermectin against female Onchocerca volvulus: further analysis of a clinical trial in the Republic of Cameroon indicating two distinct killing mechanisms. Parasitology 130(Pt 4):447-453. https:// doi.org/10.1017/s0031182004006766

Fendt J, Hamm DM, Banla M, Schulz-Key H, Wolf H, HellingGiese G, Heuschkel C, Soboslay PT (2005) Chemokines in onchocerciasis patients after a single dose of ivermectin. Clin Exp Immunol 142(2):318-326. https://doi.org/10.1111/j.13652249.2005.02910.x

Fobi G, Gardon J, Kamgno J, Aimard-Favennec L, Lafleur C, Gardon-Wendel N, Brian O, Boussinesq M (2005) A randomized, double-blind, controlled trial of the effects of ivermectin at normal and high doses, given annually or three-monthly, against O. volvulus: ophthalmological results. Trans Roy Soc Trop Med Hyg 99:279-288

Forrer A, Wanji S, Obie ED, Nji TM, Hamill L, Ozano K, Piotrowski H, Dean L, Njouendou AJ, Ekanya R, Ndongmo WPC, Fung EG, Nnamdi DB, Abong RA, Beng AA, Eyong ME, Ndzeshang BL, Nkimbeng DA, Teghen S, Suireng A, Ashu EE, Kah E, Murdoch MM, Thomson R, Theobald S, Enyong P, Turner JD, Taylor MJ (2021) Why onchocerciasis transmission persists after 15 annual ivermectin mass drug administrations in South-West Cameroon. BMJ Glob Health 6(1):e003248. https://doi.org/10.1136/bmjgh-2020-003248

Fischer C, Ibiricu Urriza I, Bulman CA, Lim K, Gut J, LachauDurand S, Engelen M, Quirynen L, Tekle F, Baeten B, Beerntsen B, Lustigman S, Sakanari J (2019) Efficacy of subcutaneous doses and a new oral amorphous solid dispersion formulation of flubendazole on male jirds (Meriones unguiculatus) infected with the filarial nematode Brugia pahangi. PLoS Negl Trop Dis 13(1):e0006787. https://doi.org/10.1371/journ al.pntd.0006787

Gandjui NVT, Njouendou AJ, Gemeg EN, Fombad FF, Ritter M, Kien CA et al (2021) Establishment of an in vitro culture system to study the developmental biology of Onchocerca volvulus with implications for anti-Onchocerca drug discovery and screening. PLoS Neg1 Trop Dis 15(2):e0008513. https://doi. org/10.1371/journal.pntd.0008513

Gardon J, Boussinesq M, Kamgno J, Gardon-Wendel N, DemangaNgangue DBO (2002) Effects of standard and high doses of ivermectin on adult worms of Onchocerca volvulus: a randomised controlled trial. Lancet 360(9328):203-210. https:// doi.org/10.1016/S0140-6736(02)09456-4

Gillon J-Y, Dennison J, van den Berg F, Delhomme S, Dequatre Cheeseman K, Peña Rossi C, Strub Wourgaft N, Specht
S, Pedrique B, Monnot F, Skrabs S, Rodriguez M-L, Stass H (2021) Safety, tolerability and pharmacokinetics of emodepside, a potential novel treatment for onchocerciasis (river blindness), in healthy male subjects. Brit Jnl Clinical Pharma 1-12. https:// doi.org/10.1111/bcp.14816

Global Burden of Disease (2018). Keys Facts. [(Accessed on 24 May 2021)] Available online: https://www.who.int/news-room/factsheets/detail/onchocerciasis.

Greene BM, Taylor HR, Cupp EW, Murphy RP, White AT, Aziz MA, Schulz-Key H, D’Anna SA, Newland HS, Goldschmidt LP, Auer C, Handsen AP, Freeman SV, Reber EW, Williams MP (1985) Comparison of ivermectin and diethylcarbamazine in the treatment of onchocerciasis. N Engl J Med 313(3):133-138. https:// doi.org/10.1056/NEJM198507183130301

Greene BM, Dukuly ZD, Muñoz B, White AT, Pacqué M, Taylor HR (1991) A comparison of 6-, 12-, and 24-monthly dosing with ivermectin for treatment of onchocerciasis. J Infect Dis 163(2):376-380. https://doi.org/10.1093/infdis/163.2.376

Grobusch MP, Kombila M, Autenrieth I et al (2003) No evidence of Wolbachia endosymbiosis with Loa loa and Mansonella perstans. Parasitol Res 90:405-408. https://doi.org/10.1007/ s00436-003-0872-z

Harder A, Holden-Dye L, Walker R, Wunderlich F (2005) Mechanisms of action of emodep side. Parasitol Res 97(Suppl 1):1-10

Hermans PG, Hart CA, Trees AJ (2001) In vitro activity of antimicrobial agents against the endosymbiont Wolbachia pipientis. J Antimicrob Chemother 47(5):659-663. https://doi.org/10.1093/ jac/47.5.659

Hoerauf A, Volkmann L, Hamelmann C, Adjei O, Autenrieth IB, Fleischer B, Büttner DW (2000) Endosymbiotic bacteria in worms as targets for a novel chemotherapy in filariasis. Lancet 355(9211):1242-1243. https://doi.org/10.1016/S0140-6736(00) 02095-X

Hoerauf A, Mand S, Adjei O, Fleischer B, Büttner DW (2001) Depletion of wolbachia endobacteria in Onchocerca volvulus by doxycycline and microfilaridermia after ivermectin treatment. The Lancet 357(9266):1415-1416. https://doi.org/10.1016/s01406736(00)04581-5

Hoerauf A, Mand S, Volkmann L, Büttner M, Marfo-Debrekyei Y, Taylor M, Adjei O, Büttner DW (2003) Doxycycline in the treatment of human onchocerciasis: Kinetics of Wolbachia endobacteria reduction and of inhibition of embryogenesis in female Onchocerca worms. Microbes Infect 5(4):261-273. https://doi.org/10. 1016/s1286-4579(03)00026-1

Hoerauf A, Specht S, Büttner M, Pfarr K, Mand S, Fimmers R, MarfoDebrekyei Y, Konadu P, Debrah AY, Bandi C, Brattig N, Albers A, Larbi J, Batsa L, Taylor MJ, Adjei O, Büttner DW (2008) Wolbachia endobacteria depletion by doxycycline as antifilarial therapy has macrofilaricidal activity in onchocerciasis: a randomized placebo-controlled study. Med Microbiol Immunol 197(3):295-311. https://doi.org/10.1007/s00430-007-0062-1

Hong WD, Benayoud F, Nixon GL, Ford L, Johnston KL, Clare RH, Cassidy A, Dan C, Siu A, Shiotani M, Webborn PJH, Kavanagh S, Aljayyoussi G, Murphy E, Steven A, Archer J, Struever D, Frohberger SJ, Ehrens A, Hübner MP, Hoerauf A, Roberts AP, ATM H, Tate EW, Serwa RA, Leung SC, Qie L, Berry NG, Gusovsky F, Hemingway J, Turner JD, Taylor MJ, Ward SA, O'Neill PM (2019) AWZ1066S, a highly specific anti-Wolbachia drug candidate for a short-course treatment of filariasis. Proc Natl Acad Sci U S A 116(4):1414-1419. https://doi.org/10.1073/pnas

Hübner MP, Koschel M, Struever D, Nikolov V, Frohberger SJ, Ehrens A et al (2019) In vivo kinetics of Wolbachia depletion by ABBV4083 in L. sigmodontis adult worms and microfilariae. PLoS Negl Trop Dis 13(8):e0007636. https://doi.org/10.1371/journal. pntd.0007636 
Hübner MP, Ehrens A, Koschel M, Dubben B, Lenz F, Frohberger SJ, Specht S, Quirynen L, Lachau-Durand S, Tekle F, Baeten B, Engelen M, Mackenzie CD, Hoerauf A (2019b) Macrofilaricidal efficacy of single and repeated oral and subcutaneous doses of flubendazole in Litomosoides sigmodontis infected jirds. PLoS Negl Trop Dis 13(1):e0006320. https://doi.org/10.1371/journal. pntd.0006320

Hübner MP, Martin C, Specht S, Koschel M, Dubben B, Frohberger SJ, Ehrens A, Fendler M, Struever D, Mitre E, Vallarino-Lhermitte N, Gokool S, Lustigman S, Schneider M, Townson S, Hoerauf A, Scandale I (2020) Oxfendazole mediates macrofilaricidal efficacy against the filarial nematode Litomosoides sigmodontis in vivo and inhibits Onchocerca spec motility in vitro. PLoS Negl Trop Dis 14(7):e0008427. https://doi.org/10.1371/journal. pntd.0008427

Irschik H, Jansen R, Hofle G, Gerth K, Reichenbach H (1985) The corallo-pyronins, new inhibitors of bacterial RNA synthesis fromMyxobacte-ria. J Antibiot (tokyo) 38:145-152

Janko C, Geyer J (2013) Moxidectin has a lower neurotoxic potential but comparable brain penetration in P-glycoprotein-deficient CF-1 mice compared to ivermectin. J Vet Pharmacol Ther 36(3):275-284

Jawahar S, Tricoche N, Bulman CA, Sakanari J, Lustigman S (2021) Drugs that target early stages of Onchocerca volvulus: a revisited means to facilitate the elimination goals for onchocerciasis. PLoS Negl Trop Dis 15(2):e0009064. https://doi.org/10.1371/journal. pntd.0009064

Jittamala P, Monteiro W, Smit MR, Pedrique B, Specht S, Chaccour CJ, Dard C, Del Giudice P, Khieu V, Maruani A, Failoc-Rojas VE, Sáez-de-Ocariz M, Soriano-Arandes A, Piquero-Casals J, Faisant A, Brenier-Pinchart MP, Wimmersberger D, Coulibaly JT, Keiser J, Boralevi F, Sokana O, Marks M, Engelman D, Romani L, Steer AC, von Seidlein L, White NJ, Harriss E, Stepniewska K, Humphreys GS, Kennon K, Guerin PJ, Kobylinski KC (2021) A systematic review and an individual patient data meta-analysis of ivermectin use in children weighing less than fifteen kilograms: is it time to reconsider the current contraindication? PLoS Negl Trop Dis 15(3):e0009144. https://doi.org/10.1371/journal.pntd. 0009144

Johnston KL, Ford L, Umareddy I, Townson S, Specht S, Pfarr K, Hoerauf A, Altmeyer R, Taylor MJ (2014) Repurposing of approved drugs from the human pharmacopoeia to target Wolbachia endosymbionts of onchocerciasis and lymphatic filariasis. Int. J. Parasitol: Drugs Drug Resist. 4(3):278-86

Kamgno J, Gardon J, Gardon-Wendel N, Demanga-Ngangue DBO, Boussinesq M (2004) Adverse systemic reactions to treatment of onchocerciasis with ivermectin at normal and high doses given annually or three-monthly. Trans R Soc Trop Med Hyg 98(8):496-504. https://doi.org/10.1016/j.trstmh.2003.10.018

Kamgno J, Pion SD, Chesnais CB, Bakalar MH, D'Ambrosio MV, Mackenzie CD, Nana-Djeunga HC, Gounoue-Kamkumo R, Njitchouang GR, Nwane P, Tchatchueng-Mbouga JB, Wanji S, Stolk WA, Fletcher DA, Klion AD, Nutman TB, Boussinesq M (2017) A Test-and-Not-Treat strategy for onchocerciasis in Loa loa-endemic areas. N Engl J Med 377(21):2044-2052. https:// doi.org/10.1056/NEJMoa1705026

Katabarwa MN, Eyamba A, Nwane P, Enyong P, Kamgno J et al (2013) Fifteen years of annual masstreatment of onchocerciasis with ivermectin have not interrupted transmission in the west region ofcameroon. J Parasitol Res 2013:420928. https://doi.org/10. $1155 / 2013 / 420928$

Kempf DJ, Marsh KC (2020) Assembling pharma resources to tackle diseases of underserved populations. ACS Med Chem Lett 11(6):1094-1100

Kiki-Mvouaka S, Ménez C, Borin C, Lyazrhi F, Foucaud-Vignault M, Dupuy J, Collet X, Alvinerie M, Lespine A (2010) Role of P-glycoprotein in the disposition of macrocyclic lactones: a comparison between ivermectin, eprinomectin, and moxidectin in mice. Drug Metab Dispos 38(4):573-580. https://doi.org/10. 1124/dmd.109.030700

Klarmann-Schulz U, Specht S, Debrah AY, Batsa L, Ayisi-Boateng NK, Osei-Mensah J, Mu barik Y, Konadu P, Ricchiuto A, Fimmers R, Arriens S, Dubben B, Ford L, Taylor M, Hoerauf A (2017) Comparison of doxycycline, minocycline, doxycycline plus albendazole and albendazole alone in their efficacy against onchocerciasis in a randomized, open-label, pilot trial. PLoS Negl Trop Dis 11(1):e0005156. https://doi.org/10.1371/journal. pntd.0005156

Korth-Bradley JM, Parks V, Chalon S, Gourley I, Matschke K, Gossart S, Bryson P, Fleckenstein L (2011) Excretion of moxidectin into breast milk and pharmacokinetics in healthy lactating women. Antimicrob Agents Chemother 55(11):5200-5204. https://doi. org/10.1128/AAC.00311-11

Korth-Bradley JM, Parks V, Patat A, Matschke K, Mayer P, Fleckenstein L (2012) Relative bioavailability of liquid and tablet formulations of the antiparasitic moxidectin. Clin Pharmacol Drug Dev 1:32-37

Krücken J, HoldenDye L, Keiser J, Prichard R, Townson S, Makepeace BL, Hübner MP, Hehnel SR, Scandale I, Harder A, Kulke D (2021) Development of emodepside as a possible adulticidal treatment for human onchocerciasis-the fruit of a successful industrial-academic collaboration. PloS Path 17(7):e1009682

Kulke D, von Samson-Himmelstjerna G, Miltsch SM, Wolstenholme AJ, Jex AR et al (2014) Characterization of the Ca2+ -gated and voltage-dependent $\mathrm{K}+$-channel Slo- 1 of nematodes and its interaction with emodepside. PLoS Negl Trop Dis 8(12):e3401. https://doi.org/10.1371/journal.pntd.0003401

Lacey E (1990) Mode of action of benzimidazoles. Parasitol Today $6: 112-115$

Lachau-Durand S, Lammens L, van der Leede B, Van Gompel J, Bailey G, Engelen M, Lampo A (2019) Preclinical toxicity and pharmacokinetics of a new orally bioavailable flubendazole formulation and the impact for clinical trials and risk/benefit to patients. PLoS Negl Trop Dis 13(1):e0007026. https://doi.org/10.1371/ journal.pntd.0007026

Lariviere M, Aziz M, Weimann D, Ginoux J, Gaxotte P, Vingtain P, Beauvais B, Deroin F, Schulz-Key H, Baset D, Sarfati C (1985) Double-blind study of ivermectin and diethylcarbamazine in African onchocerciasis patients with ocular involvement. Lancet 326(8448):174-177. https://doi.org/10.1016/s0140-6736(85) 91496-5

Larivière M, Beauvais B, Derouin F, Basset D, Basset A, Sarfati C (1987) L'Ivermectine dans le traitement et la prophylaxie de l'onchocercose humaine [Ivermectin in the treatment and prevention of human onchocerciasis]. Ann Med Interne (Paris) 138(1):49-51 (French)

Larivière M, Beauvais B, Aziz M, Garin JF, Abeloos J, Derouin F, Bamba M, Bossebceuf C, Ferlytherizol M, Sarfati C et al (1989) A study in the Ivory Coast (1985-1987) of the efficacy and tolerance of ivermectin (Mectizan) in human onchocerciasis. I. A comparative double-blind study of 220 patients with onchocerciasis treated with a single oral dose of 100,150 or $200 \mathrm{mcg} / \mathrm{kg}$. Bull Soc Pathol Exot Filiales 82(1):35-47 (French)

Lakwo TL, Gasarasi DB (2006) Non-adherence to community directed treatment with ivermectin for onchocerciasis control in Rungwe district, southwest Tanzania. East Afr Med J 83(6):326-332. https://doi.org/10.4314/eamj.v83i6.9440

Lenk EJ, Moungui HC, Boussinesq M, Kamgno J, Nana-Djeunga HC, Fitzpatrick C, Peultier A, Klion AD, Fletcher DA, Nutman TB, Pion SD, Niamsi-Emalio Y, Redekop WK, Severens JL, Stolk WA (2020) A Test-and-Not-Treat strategy for onchocerciasis elimination in Loa loa-coendemic areas: Cost Analysis of a Pilot 
in the Soa Health District, Cameroon. Clin Infect Dis: an Official Publication of the Infectious Diseases Society of America 70(8):1628-1635. https://doi.org/10.1093/cid/ciz461

Longo M, Zanoncelli S, Messina M, Scandale I, Mackenzie C, Geary T, Marsh K, Lindley D, Mazue G (2014) In vivo preliminary investigations of the effects of the benzimidazole anthelmintic drug flubendazole on rat embryos and fetuses. Reprod Toxicol 49:33-42. https://doi.org/10.1016/j.reprotox.2014.06.009

Mabey D, Whitworth JA, Eckstein M, Gilbert C, Maude G, Downham M (1996) The effects of multiple doses of ivermectin on ocular onchocerciasis. A Six-Year Follow-up Ophthalmology 103(7):1001-1008. https://doi.org/10.1016/s0161-6420(96) 30574-5

Mackenzie CD, Geary TG (2011) Flubendazole, a potentially valuable macrofilaricide for lymphatic filariasis and onchocerciasis field programs. Expert Review of Anti- Infective Therapy 9:497-501

Makenga Bof JC, Maketa V, Bakajika DK, Ntumba F, Mpunga D, Murdoch ME, Hopkins A, Noma MM, Zouré H, Tekle AH, Katabarwa MN, Lutumba P (2015) Onchocerciasis control in the Democratic Republic of Congo (DRC): challenges in a postwar environment. Trop Med Int Health 20(1):48-62. https://doi. org $/ 10.1111 /$ tmi. 12397

Mandro M, Siewe Fodjo JN, Dusabimana A, Mukendi D, Haesendonckx S, Lokonda R, Nakato S, Nyisi F, Abhafule G, Wonya'rossi D, Hotterbeekx A, Abrams S, Colebunders R, (2020) Single versus multiple dose ivermectin regimen in onchocerciasis-infected persons with epilepsy treated with phenobarbital: a randomized clinical trial in the Democratic Republic of Congo. Pathogens 9(3):205. https://doi.org/10.3390/pathogens9030205

Masud H, Qureshi TQ, Dukley M (2009) Effects of ivermectin with and without doxycycline on clinical symptoms of onchocerciasis. J Coll Physicians Surg Pak 19(1):34-38

Michiels M, Hendriks R, Heykants J, van den Bossche H (1982) The pharmacokinetics of mebendazole and flubendazole in animals and man. Arch Int Pharmacodyn Ther 256(2):180-191

Milton P, Hamley JID, Walker M, Basáñez MG (2020) Moxidectin: an oral treatment for human onchocerciasis. Expert Review of Anti-Infective Therapy 1-15. https://doi.org/10.1080/14787210. 2020.1792772

Miltsch SM, Krücken J, Demeler J, Janssen IJ, Krüger N, Harder A, von Samson-Himmelstjerna G (2012) Decreased emodepside sensitivity in unc-49 $\gamma$-aminobutyric acid (GABA)-receptor-deficient Caenorhabditis elegans. Int J Parasitol 42(8):761-770. https:// doi.org/10.1016/j.ijpara.2012.05.009

Morris CP, Evans H, Larsen SE, Mitre E (2013) A comprehensive, model-based review of vaccine and repeat infection trials for filariasis. Clin Microbiol Rev 26(3):381-421. https://doi.org/10. 1128/CMR.00002-13

Mössinger J, Schulz-Key H, Dietz K (1988) Emergence of Onchocerca volvulus microfilariae from skin snips before and after treatment of patients with ivermectin. Trop Med Parasitol 39(4):313-316

Mounsey KE, Bernigaud C, Chosidow O, McCarthy JS (2016) Prospects for moxidectin as a new oral treatment for human scabies. PLoS Negl Trop Dis 10(3):e0004389. https://doi.org/10.1371/journal. pntd.0004389

Muñoz J, Ballester MR, Antonijoan RM, Gich I, Rodríguez M, Colli E, Gold S, Krolewiecki AJ (2018) Safety and pharmacokinetic profile of fixed-dose ivermectin with an innovative $18 \mathrm{mg}$ tablet in healthy adult volunteers. PLoS Negl Trop Dis 12(1):e0006020. https://doi.org/10.1371/journal.pntd.0006020

Murdoch I, Abiose A, Babalola O, Bird A, Cousens S, Evans J, Jones B (1994) Ivermectin and onchocercal optic neuritis: short-term effects. Eye (lond) 8(Pt 4):456-461. https://doi.org/10.1038/eye. 1994.108
Mwetta E, Hills E (1994) Community treatment with ivermectin for onchocerciasis in the east Usambara mountains. East Afr Med J 71(12):790-791

Newland HS, White AT, Greene BM, D'anna SA, Keyvan-Larijani E, Aziz MA, Williams PN, Taylor HR (1988) Effect of single-dose invermectin therapy on human Onchocerca volvulus infection with onchocercal ocular involvement. Brit J Ophthl 72:561-569

NTD Modelling Consortium Onchocerciasis Group (2019) The World Health Organization 2030 goals for onchocerciasis: insights and perspectives from mathematical modelling: NTD Modelling Consortium Onchocerciasis Group. Gates Open Res 3:1545. https://doi.org/10.12688/gatesopenres.13067.1

Nutman TB (2020) Onchocerciasis. Hunter's tropical medicine and emerging infectious diseases. (Tenth Edition). E. T. Ryan, D. R. Hill, T. Solomon, N. E. Aronson and T. P. Endy. London: Elsevier 116: 864-871.

Ogbuagu KF, Eneanya CI (1988) A multi-centre study of the effect of Mectizan treatment on onchocercal skin disease: clinical findings. Ann Trop Med Parasitol 92(Suppl 1):S139-S145

O’Neill A, Oliva B, Storey C, Hoyle A, Fishwick C, Chopra I (2000) RNApolymerase inhibitors with activity against rifampin-resistant mutants of Staphylococcus aureus. Antimicrob Agents Chemother 44:3163-6

Opoku NO, Bakajika DK, Kanza EM, Howard H, Mambandu GL, Nyathirombo A, Nigo MM, Kasonia K, Masembe SL, Mumbere M, Kataliko K, Larbelee JP, Kpawor M, Bolay KM, Bolay F, Asare S, Attah SK, Olipoh G, Vaillant M, Halleux CM, Kuesel AC (2018) Single dose moxidectin versus ivermectin for Onchocerca volvulus infection in Ghana, Liberia, and the Democratic Republic of the Congo: a randomised, controlled, double-blind phase 3 trial. Lancet 392(10154):1207-1216. https:// doi.org/10.1016/S0140-6736(17)32844-1 (Erratum in: Lancet 392(10154):1196)

Osei-Atweneboana MY, Eng JK, Boakye DA, Gyapong JO, Prichard RK (2007) Prevalence and intensity of Onchocerca volvulus infection and efficacy of ivermectinin endemic communities in Ghana: a two-phase epidemiological study. Lancet 369:2021-2029

Patton JB, Bennuru S, Eberhard ML, Hess JA, Torigian A, Lustigman $S$ et al (2018) Development of Onchocerca volvulus in humanized NSG mice and detection of parasite biomarkers in urine and serum. PLoS Negl Trop Dis 12(12):e0006977. https://doi.org/10. 1371/journal.pntd.0006977

Pion SD, Grout L, Kamgno J, Nana-Djeunga H, Boussinesq M (2011) Individual host factors associated with Onchocerca volvulus microfilarial densities 15,80 and 180 days after a first dose of ivermectin. Acta Trop 120(Suppl 1):S91-S99. https://doi.org/10. 1016/j.actatropica.2010.05.004

Pionnier N, Sjoberg H, Furlong-Silva J, Marriott A, Halliday A, Archer J, Steven A, Taylor MJ, Turner JD (2020) Eosinophil-mediated immune control of adult filarial nematode infection can proceed in the absence of IL-4 receptor signaling. J Immunol 205(3):731740. https://doi.org/10.4049/jimmunol.1901244

Plaisier AP, Alley ES, Boatin BA, Van Oortmarssen GJ, Remme H, De Vlas SJ, Bonneux L, Habbema JD (1995) Irreversible effects of ivermectin on adult parasites in onchocerciasis patients in the Onchocerciasis Control Programme in West Africa. J Infect Dis 172(1):204-210. https://doi.org/10.1093/infdis/172.1.204

Prichard R, Menez C, Lespine A (2012) Moxidectin and the avermectins: consanguinity but not identity. Int J Parasitol Drugs Drug Resist 2:134-153

Prichard RK, Geary TG (2019) Perspectives on the utility of moxidectin for the control of parasitic nematodes in the face of developing anthelmintic resistance. Int J Parasitol Drugs Drug Resist 10:69-83. https://doi.org/10.1016/j.ijpddr.2019.06.002 
Richards FO Jr, Amann J, Arana B, Punkosdy G, Klein R, Blanco C, Lopez B, Mendoza C, Domínguez A, Guarner J, Maguire JH, Eberhard M (2007) No depletion of Wolbachia from Onchocerca volvulus after a short course of rifampin and/or azithromycin. Am J Trop Med Hyg 77(5):878-882

Risch F, Ritter M, Hoerauf A, Hübner MP (2021) Human filariasiscontributions of the Lito mosoides sigmodontis and Acanthocheilonema viteae animal model. Parasitol Res. https://doi. org/10.1007/s00436-020-07026-2

Saeger B, Schmitt-Wrede HP, Dehnhardt M, Benten WP, Krucken J et al (2001) Latrophilin-like receptor from the parasitic nematode Haemonchus contortus as target for the anthelmintic depsipeptide PF1022A. FASEB J 15:1332-1334

Sauerbrey M, Lindsay JR, Richards FO Jr (2018) Progress toward elimination of onchocerciasis in the Americas. Int Health. 10:i71-i78. https://doi.org/10.1093/inthealth/ihx039 (anti-wolbachial, macrofilaricidal treatment of filarial infections. PLoS Negl Trop Dis 14:e008930)

Saunders M, Taubert A, Dafa'alla T, Zahner H (2008) Effect of chemotherapeutic treatment on cytokine (IFNgamma, IL-2, IL-4, IL-5, IL-10) gene transcription in response to specific antigens in Brugia malayi-infected Mastomys coucha. Parasitol Res 103(5):1163-1176. https://doi.org/10.1007/s00436-008-1112-3

Schiefer A, Schmitz A, Schäberle TF, Specht S, Lämmer C, Johnston KL, Vassylyev DG, König GM, Hoerauf A, Pfarr K (2012) Corallopyronin A specifically targets and depletes essential obligate Wolbachia endobacteria from filarial nematodes in vivo. J Infect Dis 206(2):249-257. https://doi.org/10.1093/infdis/jis341

Schiefer A, Hübner MP, Krome A, Lämmer C, Ehrens A, Aden T et al (2020) Corallopyronin A for short-course anti-wolbachial, macrofilaricidal treatment of filarial infections. PLoS Negl Trop Dis 14(12):e0008930.https://doi.org/10.1371/journal.pntd.0008930

Selzer PM and Epe C (2020) Antiparasitics in animal health: Quo Vadis?Trends in Parasitology. https://doi.org/10.1016/j.pt.2020. 09.004

Senyonjo L, Oye J, Bakajika D, Biholong B, Tekle A, Boakye D et al (2016) Factors associated with ivermectin non-compliance and its potential role in sustaining Onchocerca volvulus transmission in the West Region of Cameroon. PLoSNegl Trop Dis 10(8):e0004905. https://doi.org/10.1371/journal.pntd.0004905

Shu EN, Okonkwo PO, Ogbodo SO (1997) An improved dosing schedule for ivermectin as a microfilaricidal agent against onchocerciasis. Acta Trop 68(3):269-275. https://doi.org/10.1016/s0001-706x(97) 00101-0

Sjoberg HT, Pionnier N, Aljayyoussi G, Metuge HM, Njouendou AJ, Chunda VC et al (2019) Short-course, oral flubendazole does not mediate significant efficacy against Onchocerca adult male worms or Brugia microfilariae in murine infection models. PLoS Negl Trop Dis 13(1):e0006356. https://doi.org/10.1371/journal.pntd.0006356

Soboslay PT, Newland HS, White AT, Erttmann KD, Albiez EJ, Taylor HR, Williams PN, Greene BM (1987) Ivermectin effect on microfilariae of Onchocerca volvulus after a single oral dose in humans. Trop Med Parasitol 38(1):8-10

Somo RM, Ngosso A, Dinga JS, Enyong PA, Fobi G (1993) A community-based trial of ivermectin for onchocerciasis control in the forest of southwestern Cameroon: clinical and parasitologic findings after three treatments. Am J Trop Med Hyg 48(1):9-13. https://doi.org/10.4269/ajtmh.1993.48.9

Soula G, Keita M, Sacko D, Sangare M, Bissan Y, Dembele D, Doumbo O, Kodio B, Pichard E, Ranque P (1992) Tolérance d'un traitement de collectivités rurales atteintes d'onchocercose de savane par l'ivermectine au Mali [Tolerance of ivermectin treatment of rural communities infected by savannah onchocerciasis in Mali]. Bull Soc Pathol Exot 85(1):47-52 (French)

Specht S, Mand S, Marfo-Debrekyei Y, Debrah A, Konadu P, Adjei O, Büttner D, Hoerauf A (2008) Efficacy of 2- and 4-week rifampicin treatment on the Wolbachia of Onchocerca volvulus. Parasitol Res 103(6):1303-1309

Specht S, Pfarr KM, Arriens S, Hübner MP, Klarmann-Schulz U, Koschel M, Sternberg S, Martin C, Ford L, Taylor MJ, Hoerauf A (2018) Combinations of registered drugs reduce treatment times required to deplete Wolbachia in the Litomosoides sigmodontis mouse model. PLoS Negl Trop Dis 12(1):e0006116. https://doi. org/10.1371/journal.pntd.0006116

Steel C, Lujan-Trangay A, Gonzalez-Peralta C, Zea-Flores G, Nutman TB (1994) Transient changes in cytokine profiles following ivermectin treatment of onchocerciasis. J Infect Dis 170(4):962-970. https://doi.org/10.1093/infdis/170.4.962

Stolk WA, Walker M, Coffeng LR, Basá nez MG, de Vlas SJ, (2015) Required duration of mass ivermectin treatment for onchocerciasis elimimnation in Africa: a comparative modelling analysis. Parasit Vectors 8:552. https://doi.org/10.1186/ s13071-015-1159-9

Tagboto SK, Townson S (1996) Onchocerca volvulus and O. lienalis: the microfilaricidal activity of moxidectin compared with that of ivermectin in vitro and in vivo. Ann Trop Med Parasitol 90(5):497-505. https://doi.org/10.1080/00034983.1996.11813 075

Tamarozzi F, Tendongfor N, Enyong PA, Esum M, Faragher B, Wanji S, Taylor MJ (2012) Long term impact of large scale communitydirected delivery of doxycycline for the treatment of onchocerciasis. Parasit Vectors 5:53. https://doi.org/10.1186/1756-3305-5-53

Taylor MJ, Hoerauf A (1999) Wolbachia bacteria of filarial nematodes. Parasitol Today 15(11):437-442. https://doi.org/10.1016/s01694758(99)01533-1

Taylor HR, Murphy RP, Newland HS, White AT, D’Anna SA, KeyvanLarijani E, Aziz MA, Cupp EW, Greene BM (1986) Treatment of onchocerciasis. The ocular effects of ivermectin and diethylcarbamazine. Arch Ophthalmol 104(6):863-70. https://doi.org/ 10.1001/archopht.1986.01050180097039

Taylor HR, Semba RD, Newland HS, Keyvan-Larijani E, White A, Dukuly Z, Greene BM (1989) Ivermectin treatment of patients with severe ocular onchocerciasis. Am J Trop Med Hyg 40(5):494-500. https://doi.org/10.4269/ajtmh.1989.40.494

Taylor MJ, Bandi C, Hoerauf A (2005) Wolbachia bacterial endosymbionts of filarial nematodes. Adv Parasitol 60:245-284

Taylor MJ, Hoerauf A, Bockarie M (2010) Lymphatic filariasis and onchocerciasis. Lancet 376:1175-1185

Taylor MJ, Hoerauf A, Townson S, Slatko BE, Ward SA (2014) Anti-Wolbachia drug discovery and development: safe macrofilaricides for onchocerciasis and lymphatic filariasis. Parasitol 141(1):119-127. https://doi.org/10.1017/S0031182013001108

Taylor MJ, von Geldern TW, Ford L, Hübner MP, Marsh K, Johnston KL, Sjoberg HT, Specht S, Pionnier N, Tyrer HE, Clare RH, Cook DAN, Murphy E, Steven A, Archer J, Bloemker D, Lenz F, Koschel M, Ehrens A, Metuge HM, Chunda VC, Ndongmo Chounna PW, Njouendou AJ, Fombad FF, Carr R, Morton HE, Aljayyoussi G, Hoerauf A, Wanji S, Kempf DJ, Turner JD, Ward SA (2019) Preclinical development of an oral anti-Wolbachia macrolide drug for the treatment of lymphatic filariasis and onchocerciasis. Sci Transl Med 11(483):2086. https://doi.org/ 10.1126/scitranslmed.aau2086

Tejman-Yarden N, Miyamoto Y, Leitsch D, Santini J, Debnath A, Gut J, McKerrow JH, Reed SL, Eckmann L (2013) A reprofiled drug, auranofin, is effective against metronidazole-resistant Giardia lamblia. Antimicrob Agents Chemother 57(5):2029-2035. https://doi.org/10.1128/AAC.01675-12 (PMC3632933)

Townson S, Connelly C, Dobinson A, Muller R (1987) Drug activity against Onchocerca gutturosa males in vitro: a model for chemotherapeutic research on onchocerciasis. J Helminthol 61:271-281

Townson S, Dobinson A, Connelly C, Muller R (1988) Chemotherapy of Onchocerca lienalis microfilariae in mice: a model for the 
evaluation of novel compounds for the treatment of onchocerciasis. J Helminthol 62:181-194

Townson S, Dobinson AR, Townsend J, Siemienska J, Zea-Flores G (1990) The effects of ivermectin used in combination with other known anti-parasitic drugs on adult Onchocerca guuurosa and O. volvulus in vitro. Trans R Soc Trop Med Hyg 84:411-416

Townson S, Tagboto SK (1991) The effects of ivermectin on the viability of Onchocerca Iienalis microfilariae in vitro and on their subsequent development in the blackfly vector, Simulium ornatum. Trop Med Parasitol 42:31-37

Townson (2005) Activity of the cyclooctadepsipeptide emodepside against Onchocerca gutturosa, Onchocerca lienalis and Brugia pahangi (conference abstract): Am J Trop Med Hyg : Official Journal of the American Society of Tropical Medicine and Hygiene 73(6, Suppl. S) 93-93. info:doi/

Turner JD, Tendongfor N, Esum M, Johnston KL, Langley RS, Ford L et al (2010) Macrofilaricidal activity after doxycycline only treatment of Onchocerca volvulus in an area of Loa loa co-endemicity: a randomized controlled trial. PLoS Negl Trop Dis 4(4):e660. https://doi.org/10.1371/journal.pntd.0000660

Turner HC, Walker M, Churcher TS, Osei-Atweneboana MY, Biritwum NK, Hopkins A, Prichard RK, Basá nez MG, (2014) Reaching the London Declaration on Neglected Tropical Diseases goals for onchocerciasis: aneconomic evaluation of increasing the frequency of ivermectin treatment inAfrica. Clin Infect Dis 59:923-932. https://doi.org/10.1093/cid/ciu467

Tweats DJ, Johnson GE, Scandale I, Whitwell J, Evans DB (2016) Genotoxicity of flubendazole and its metabolites in vitro and the impact of a new formulation on in vivo aneugenicity. Mutagenesis 31:309. https://doi.org/10.1093/mutage/gev070

Vingtain P, Pichard E, Ginoux J, Coulibaly SM, Bissan Y, Ranque P, Thillaye B (1988) Ivermectin and human onchocerciasis. A study of 234 onchocerciasis patients in the Republic of Mali. Bull Soc Pathol Exot Filiales 81(2):260-70 (French)

Voronin D, Tricoche N, Jawahar S, Shlossman M, Bulman CA, Fischer C, Suderman MT, Sakanari JA, Lustigman S (2019) Development of a preliminary in vitro drug screening assay based on a newly established culturing system for pre-adult fifth-stage Onchocerca volvulus worms. PLoS Negl Trop Dis 13(1):e0007108. https:// doi.org/10.1371/journal.pntd.0007108

Volkmann L, Fischer K, Taylor M, Hoerauf A (2003) Antibiotic therapy in murine filariasis (Litomosoides sigmodontis): comparative effects of doxycycline and rifampicin on Wolbachia and filarial viability. Trop Med Int Health 8(5):392-401. https://doi.org/10. 1046/j.1365-3156.2003.01040.x

von Geldern TW, Morton HE, Clark RF, Brown BS, Johnston KL, Ford L, Specht S, Carr RA, Stolarik DF, Ma J, Rieser MJ, Struever D, Frohberger SF, Koschel M, Ehrens A, Turner JD, Hübner MP, Hoerauf A, Taylor MJ, Ward SA, Marsh K, Kempf DJ (2019) Discovery of ABBV-4083, a novel analog of Tylosin A that has potent anti-Wolbachia and anti-filarial activity. PLoS Negl Trop Dis 13(2):e0007159. https://doi.org/10.1371/journal.pntd.00071 59

Walker M, Specht S, Churcher TS, Hoerauf A, Taylor MJ, Basáñez MG (2015) Therapeutic efficacy and macrofilaricidal activity of doxycycline for the treatment of river blindness. Clin Infect Dis 60(8):1199-1207. https://doi.org/10.1093/cid/ciu1152

Walker M, Stolk WA, Dixon MA, Bottomley C, Diawara L, Traoré MO, de Vlas SJ, Basáñez MG (2017a) Modelling the elimination of river blindness using long-term epidemiological and programmatic data from Mali and Senegal. Epidemics 18:4-15. https:// doi.org/10.1016/j.epidem.2017.02.005

Walker M, Pion SDS, Fang H, Gardon J, Kamgno J, Basáñez MG, Boussinesq M (2017b) Macrofilaricidal efficacy of repeated doses of ivermectin for the treatment of river blindness. Clin Infect Dis 65(12):2026-2034. https://doi.org/10.1093/cid/cix616
Wan Sulaiman WA, Kamtchum-Tatuene J, Mohamed MH, Ramachandran V, Ching SM, Sazlly Lim SM, Hashim HZ, Inche Mat LN, Hoo FK, Basri H (2019) Anti-Wolbachia therapy for onchocerciasis \& lymphatic filariasis: current perspectives. Indian J Med Res 149(6):706-714. https://doi.org/10.4103/ijmr.IJMR_454_17

Wanji S, Tendongfor N, Nji T, Esum M, Che JN, Nkwescheu A, Alassa F, Kamnang G, Enyong PA, Taylor MJ, Hoerauf A, Taylor DW (2009) Community-directed delivery of doxycycline for the treatment of onchocerciasis in areas of co-endemicity with loiasis in Cameroon. Parasit Vectors 2(1):39. https://doi.org/10.1186/ 1756-3305-2-39

Whitworth JA, Morgan D, Maude GH, Downham MD, Taylor DW (1991a) A community trial of ivermectin for onchocerciasis in Sierra Leone: adverse reactions after the first five treatment rounds. Trans R Soc Trop Med Hyg 85(4):501-505. https://doi. org/10.1016/0035-9203(91)90236-r

Whitworth JA, Gilbert CE, Mabey DM, Maude GH, Morgan D, Taylor DW (1991b) Effects of repeated doses of ivermectin on ocular onchocerciasis: community-based trial in Sierra Leone. Lancet 338(8775):1100-1103. https://doi.org/10.1016/0140-6736(91) 91963-u

Whitworth JA, Morgan D, Maude GH, Luty AJ, Taylor DW (1992a) A community trial of ivermectin for onchocerciasis in Sierra Leone: clinical and parasitological responses to four doses given at sixmonthly intervals. Trans R Soc Trop Med Hyg 86(3):277-280. https://doi.org/10.1016/0035-9203(92)90308-y

Whitworth JA, Luty AJ, Maude GH, Morgan D, Downham MD, Taylor DW (1992b) Ivermectin does not reduce the burden of itching in an onchocerciasis endemic community. Trans R Soc Trop Med Hyg 86(3):281-283. https://doi.org/10.1016/0035-9203(92) 90309-z

Whitworth JA, Downham MD, Lahai G, Maude G (1996a) A community trial of ivermectin for onchocerciasis in Sierra Leone: compliance and parasitological profiles after three and a half years of intervention. Trop Med Int Health 1(1):52-58. https://doi.org/10.1046/j.1365-3156. 1996.d01-3.x

Whitworth JA, Maude GH, Downham MD (1996) Clinical and parasitological responses after up to 6.5 years of ivermectin treatment for onchocerciasis. Trop Med Int Health 1(6):786-93. https://doi. org/10.1111/j.1365-3156.1996.tb00111.x

White AT, Newland HS, Taylor HR, Erttmann KD, Larijani EK, Nara A, Aziz MA, D’Anna SA, Williams PN, Greene BM (1987) Controlled trial and dose-finding study of ivermectin for treatment of onchocerciasis. J Infect Dis 156(3):463-470. https://doi.org/10. 1093/infdis/156.3.463

Wolstenholme AJ, Maclean MJ, Coates R, McCoy CJ, Reaves BJ (2016) How do the macrocyclic lactones kill filarial nematode larvae? Invert Neurosci 16(3):7. https://doi.org/10.1007/ s10158-016-0190-7

World Health Organisation (2000): Onchocerciasis (river blindness). The World Health Organization, Geneva. Fact Sheet No. 95.

World Health Organisation (2014) African Programme for Onchocerciasis Control: progress report, 2013-2014. Wkly Epidemiol Rec 89(49):551-560

World Health Organisation (2020) Ending the neglect to attain the sustainable Development. A road map for neglected tropical diseases 2021-2030. BYNC-SA 3.0 IGO, World Health Organization

World Health Organization (2019) World Health Organization model list of essential medicines: 21st list 2019. World Health Organization, Geneva

Youssef MY, Sadaka HA, Eissa MM, el-Ariny AF (1995) Topical application of ivermectin for humanectoparasites. Am J Trop Med Hyg. 53(6):652-3. https://doi.org/10.4269/ajtmh.1995.53. 652

Zahner H, Schares G (1993) Experimental chemotherapy of filariasis: comparative evaluation of the efficacy of filaricidal compounds 
in Mastomys coucha infected with Litomosoides carinii, Acanthocheilonema viteae, Brugia malayi and B. pahangi. Acta Trop 52(4):221-266. https://doi.org/10.1016/0001-706x(93)90010-9

Zahner H, Taubert A, Harder A, Samson-Himmelstjerna GV (2001) Filaricidal efficacy of anthelmintically active cyclodepsipeptides. Int. J. Parasitol 31(13):1515-1522. https://doi.org/10.1016/ S0020-7519(01)00263-6 (ISSN 0020-7519)
Publisher's Note Springer Nature remains neutral with regard to jurisdictional claims in published maps and institutional affiliations. 